Ataş, U. A. ve Yıldırım, K. (2020). İlkokul birinci sınıf ilk okuma yazma kitabının öğretmen görüşleri bağlamında incelenmesi. Ana Dili Eğitimi Dergisi, 8(4), 1245-1268.

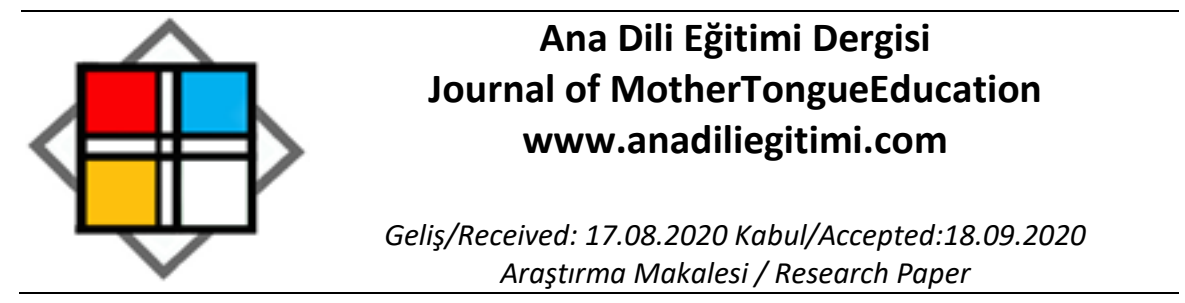

\title{
İlkokul Birinci Sınıf İlk Okuma Yazma Kitabının Öğretmen Görüşleri Bağlamında Incelenmesi $^{* * *}$
}

\author{
Umut Can ATAŞ ${ }^{* * *}$ \\ KasIm YILDIRIM ${ }^{* * * *}$
}

Öz

Yapılan bu araştırmada ilkokul birinci sınıf ilk okuma yazma kitabının öğretmen görüşleri bağlamında değerlendirilmesi amaçlanmışıı. Araştırma hem nicel hem de nitel yönleri birlikte barındırması nedeniyle açıklayııı karma yöntemle desenlenmiştir. Yapılan araştırmaya 2019-2020 eğitim-öğretim yılında, Şanlıurfa iline bağlı ilkokullarda görev yapmakta olan 191 sınıf öğretmeni katılış̧ır. Araştırma kapsamında verilerin toplanması sürecinde araştırmacı tarafından hazırlanan anket formu ve yine araştırmacı tarafından hazırlanan yarı yapılandırılmış görüşme formu kullanılmışır. Elde edilen nicel verilerin analizinde SPSS paket programdan faydalanılırken, nitel verilerin analizinde ise betimsel analiz yönteminden faydalanılmışıı. Araştırma sonucunda sınıf öğretmenlerinin 1. Sınıf Türkçe Illk Okuma ve Yazma Ders Kitabı'nı genel anlamıyla "Yeterli" olarak gördükleri ortaya çıkarılmıştır. Araştırmanın nitel boyutuna ilişkin sonuçlar incelendiğinde sınıf öğretmenlerinin ilk okuma ve yazma öğretimi sürecinde ders kitabından bir kaynak olarak oldukça fazla yararlandıkları, ders kitabının sesi hissettirme ve tanıma ile ilgili bölümlerini yeterli görürken; hece ve kelimeye geçiş bölümlerini ise yetersiz gördükleri sonuçlarına ulaşıımışır.

Anahtar Kelimeler: Sınıf Öğretmenleri, Okuma ve Yazma Öğretimi, Ders Kitapları

\section{Exploring the Opinions of Elementary School Classroom Teachers on First Grade Turkish Reading and Writing Textbook}

\begin{abstract}
In this present research, it was aimed to evaluate the first grade Turkish Reading and Writing Textbook through the opinions of the elementary school classroom teachers. The research employed explanatory mixed methods design since it contained both quantitative and qualitative stages together. A total of 191 elementary school classroom teachers working at elementary schools in Turkey's Şanlıurfa province in the 2019-2020 school year participated in the research. In the process of collecting data, a questionnaire form and a semi-structured interview form prepared by the researcher were used. While SPSS package program was used in the analysis of the quantitative data obtained, descriptive analysis method was used in the analysis of the qualitative data. As a result of the research, it was revealed that the elementary school classroom teachers regarded the first grade Turkish Reading and Writing Textbook as sufficient in this context. When the results related to the qualitative stage of the research were examined, while the teachers who make use of the textbook as a resource during the reading and writing teaching process, consider the sections of the textbook related to making the phonics feel and recognition sufficient the syllable and word transition sections were deemed insufficient.
\end{abstract}

Keywords: Elementary School Classroom Teachers, Reading and Writing Instruction, Textbooks

\footnotetext{
* Bu makale birinci yazarının yüksek lisans tez çalışmasından üretilmiştir.

${ }^{* *}$ Araştırmanın etik kurulu izni: Şanlıurfa M.E.M.: 13.11.2018, 26292541-44-E.21633384.

*** Yüksek Lisans Öğrencisi, Muğla Sıtkı Koçman Üniversitesi, Eğitim Fakültesi, Temel Eğitim Bölümü, Muğla, ucanatas1804@gmail.com, ORCID: 0000-0003-3080-2736

**** Dr., Muğla Sıtkı Koçman Üniversitesi, Eğitim Fakültesi, Temel Eğitim Bölümü, Muğla,

kasimyildirim@mu.edu.tr, ORCID: 0000-0003-1406-709X
} 


\section{Giriş}

Eğitim ve öğretimin var olduğu zamanlardan bu yana, basılı materyaller eğitim ve öğretim konuları bağlamında vazgeçilemeyen öğretim materyalleri arasında bulunmaktadır. Basılı materyallerin kolay ulaşılabilir olması, öğrenciye bireysel çalışma fırsatı sağlaması, öğreticiye rehberlik edebiliyor olması, öğrenme ve öğretme sürecinde ekonomik bir kaynak olması gibi sebepler, basılı materyallerin vazgeçilememe sebepleri olarak gösterilebilmektedir. Çocukların ailelerinden uzaklaşıp farklı bir çevre ile tanıştıkları okula başlama sürecinde, yani temel eğitim kademesinde, okuma becerileri ile ilk tanışmaları ve okuma alışkanlığı kazanabilmeleri için basıı materyallerin nasıl hazırlandığı, uygunluğu, kullanışlılığı gibi faktörler oldukça önemlidir (Küçükahmet, 2000).

Eğitimde başvurulan en temel ve birincil kaynaklar ders kitaplarıdır. Öğretmenlerin sınıf içi etkinliklerinin oluşturulmasında önemli bir yer kaplayan ders kitapları, öğrencilerin bilgiye en kolay ve hızlı ulaşma yolunu sunmaktadır. Farklı ülkelerin eğitim ve öğretim programları incelendiğinde, ders kitaplarının gelişen teknolojiye rağmen genel itibariyle hala birincil kaynak olarak algılandığı görülmektedir (Öcal ve Yiğittir, 2007; Nalçacı, 2011). Örneğin Japon öğretmenler, okulda derste iken deprem olduğunda, kurtarıması gereken öncelikler arasında kitaplarını da belirtmişlerdir (Arslan ve Özpınar, 2008).

Ders kitaplarının maliyetlerinin diğer eğitim materyallerinin maliyetlerine göre daha az olması, kolay ulaşılabilir olması, öğrenmeyi bireyselleştirmesi ve yapılandırması ile eğitimde fırsat eşitliğine imkân sağlamasına da yardımcı olmaktadır. Gelişen teknoloji ve değişen toplumun ve bireyin ihtiyaçları doğrultusunda, öğrenme ve öğretme süreçlerinde de farklı kaynakların kullanılması oldukça revaçtadır. Bu kaynakların kullanımı doğrultusunda, bazı bireylerin eğitim ve öğretim olanaklarından diğer bireylere göre daha az yararlanabilme potansiyellerinin bulunduğu göz ardı edilememektedir. Nitelik açısından oldukça iyi olabilecek olan ders kitaplarının öğrenme ve öğretme sürecinde yürütülecek etkinliklerin uygulanmasında kullanılması, eğitim ve öğretimde fırsat eşitliği konusunda da oldukça önemli bir noktayı teşkil etmektedir (Bakar, Keleş ve Koçakoğlu, 2009).

Özellikle anadil öğretiminde ders kitaplarından oldukça fazla yararlanılmaktadır. Bireyin sahip olması hedeflenen temel dil becerileri olan okuma, yazma, konuşma, dinleme ve dil bilgisini kazandırmada ders kitaplarının sahip olduğu işlevler öne çıkmaktadır. Ders kitaplarında yer alan metinler, görseller, metinlerde işlenen konular, metin içi ve dışı sorular ve etkinlikler temel dil becerilerini geliştirmeyi hedef almaktadır (Şahin, 2008). Yapılandırmacı yaklaşımın hedefleri doğrultusunda, bilgiyi kendisi keşfeden bireyler yetiştirmek için ders kitaplarının niteliklerini arttırmak hedeflenmektedir. Bu bağlamda ders kitaplarında bulunan öğrenme ve öğretme süreci etkinliklerinin daha çok yaparak ve yaşayarak öğrenme ilkesine dayanması gerekmektedir. Ders kitabının içerdiği görseller ve metinlerin, günlük yaşamla ilintili, günlük yaşamdan alınmış olması, öğrencilerin dikkatlerini çekebiliyor olması gibi nitelikler, öğrenme ve öğretme sürecinin niteliğini de birincil dereceden etkileyebilmektedir (Kabapınar, 2009).

Gelişen teknoloji ile yazılı materyaller artık sadece kâğıt değil elektronik ortamlarda da bulunmaya başlanmıştır. Kitapların artık internet ortamında e kitap olarak bulunması; tablet, bilgisayar, telefon gibi cihazlar vasıtasıyla ekrandan okuma kavramının ortaya çıkmasını sağlamıştır. Dünyanın ve ülkemizin teknolojik alt yapı şartları göz önüne alındığında ekran okumanın yaygınlaşması sınırlı alanlarda mümkün olabilmektedir. Bilginin teknolojik olarak yayılmasının önünde farklı alt yapısal problemlerin olması, ders kitaplarının kullanılma gereğinin bir kez daha görülmesine yol açabilmektedir. Ders kitaplarının, öğretim programları ve ders planları doğrultusunda, bir kaynak tarafından hazırlanması ve hedef kitleye ulaştırılması ile öğrenme ve öğretme sürecinin kalitesi arttırılabilmektedir (Demirel, Seferoğlu ve Yağcl, 2004; Geçit ve Yarar, 2010).

Eğitimde geçmişten günümüze güncelliğini ve önemini koruyan ders kitapları nasıl olmalıdır? Öğretimdeki yeri ve önemi ne kadar olmalıdır? Hazırlanan ders kitapları, öğrenme ve öğretme sürecinin niteliğine, öğrencilerin ve öğretmenlerin ihtiyaçlarına cevap verebilmekte midir? Gibi sorular bu araştırmanın yapılması amacıyla yola çıkılması konusunda yol gösterici olmuşlardır.

Ülkemiz genelinde bakıldığında ilk okuma ve yazma öğretimi bağlamında ders kitaplarının incelenmesine yönelik çalışmalar genel anlamıyla metinler, görseller ve illüstrasyonlar çerçevesinde gerçekleştirilmiştir (Liman, 2007). Yine ülkemiz genelinde öğretmen görüşlerine dayalı olarak ilkokul 
Birinci Sınıf Türkçe Ders Kitabı, Öğrenci Çalışma Kitabı ve Öğretmen Kılavuz Kitabı́nın incelendiği bir başka çalışmaya daha rastlanılmıştır (Şahin, 2008). Yapılan çalışmalar incelendiğinde mevcut çalışmaların azlığı ve güncel olmamaları gibi durumlar, bu araştırmanın da probleminin geliştirilmesine ön ayak olmuştur.

Genel anlamda bu araştırmanın problemi, ilkokul birinci sınıf öğretmenlerinin, birinci sınıf ilk okuma yazma ders kitabına yönelik görüşleri nasıldır? Şeklindedir.

Bu kapsamda araştırmada, ilkokul birinci sınıflarda öğrenme-öğretme sürecinin temel materyallerinden olan ilk okuma yazma kitabı niteliklerinin sınıf öğretmenlerinin görüşleri çerçevesinde incelenmesi ve ders kitabının bu bağlamda değerlendirilmesi amaçlanmıştır.

Araştırma doğrultusunda ilgili problem çerçevesinde incelenen alt problemler ise şöyledir;

1. Sınıf öğretmenlerinin ilk okuma yazma ders kitabı hakkında genel görüşleri nelerdir?

2. Sınıf öğretmenlerinin ilk okuma yazma kitabı hakkındaki görüşleri cinsiyet değişkenine göre anlamlı bir şekilde farklılaşmakta mıdır?

3. Sınıf öğretmenlerinin ilk okuma yazma kitabı hakkındaki görüşleri yaş değişkenine göre anlamlı bir şekilde farklılaşmakta mıdır?

4. Sınıf öğretmenlerinin ilk okuma yazma kitabı hakkındaki görüşleri mesleki deneyim değişkenine göre anlamlı bir şekilde farklılaşmakta mıdır?

5. Sınıf öğretmenlerinin ilk okuma yazma kitabı hakkındaki görüşleri görev yapmakta oldukları okulun bulunduğu yerleşim birimi değişkenine göre anlamlı bir şekilde farklılaşmakta mıdır?

6. Sınıf öğretmenlerinin ilk okuma yazma kitabı hakkındaki görüşleri, mezuniyet durumları değişkenine göre anlamlı bir şekilde farklılaşmakta mıdır?

7. Sınıf öğretmenleri ilk okuma yazma kitabını MEB Ders Kitapları ve Araçları Yönetmeliği'nde bulunan ders kitabı nitelikleri bağlamında nasıl değerlendirmektedirler?

Teknolojinin hızla gelişmesi ve teknolojideki gelişmelerin eğitim alanına da yansımasıyla birlikte öğrenme-öğretme süreçleri de farklılaşmaktadır. Bu bağlamda değerlendirildiğinde öğrenme-öğretme süreçlerindeki farklılaşma öğrencilerin bireysel intiyaçları doğrultusunda ilerlemektedir. Eğitimde teknolojinin kullanılması bu bağlamda oldukça pozitif olarak değerlendirilebilirken öğrenme-öğretme sürecinde yine de en can alıcı materyal olarak ders kitapları öne çıkmaktadır. Eğitim sistemimizde sürekli olarak yapılan değişiklikler ders kitaplarının yerine sürekli olarak yeni ders kitaplarını koymaktadır. Bu bağlamda hazırlanan ders kitaplarının niteliği de tüm eğitim paydaşlarını düşündürmektedir.

Dolayısıyla yapılacak olan çalışmanın ilk okuma yazma gibi oldukça önemli bir alanda yapılıyor olması, daha önce bu alanda yapılmış kapsamlı bir çalışmanın eksikliği gibi nedenlerle birlikte söz konusu kitabın da ilk okuma yazma öğretimi kitabı olduğu göz önünde bulundurulursa yapılacak olan çalışma ve sonuçlarının oldukça fazla önem arz edeceği ön görülmektedir. Ülkemiz bağlamında ders kitapları konusunda yapılmış araştırmalar tarandığında yapılmış çalışmaların daha çok ortaokul ve ortaöğretim kademelerinde gerçekleştirildiği görülmektedir. illkokul kademesinde yapılan çalışmalar ele alındığında ise yapılan çalışmaların genel anlamıyla ders kitaplarını program hedefleri-ders kitabındaki kazanımlar, kullanılan metinlerin uygunluğu, kullanılan resimlerin uygunluğu gibi tek bir boyuttan ele alan çalışmalar olduğu görülmektedir.

Yapılan araştırmanın; illkokul 1. Sınıf Türkçe ilk Okuma ve Yazma Ders Kitabı́nı genel itibariyle ala almakta olması, ders kitabının hem program hedeflerine uygunluğunu, hem öğrenci seviyesine uygunluğunu, hem de genel itibariyle bir materyal olarak kullanılabilirlik, ekonomiklik gibi faktörleriyle birlikte ele alması nedeniyle ilgili alanyazına önemli bir kaynak teşkil edeceği öngörülmektedir.

\section{Araştırmanın Modeli}

\section{Yöntem}

Son yıllarda yapılan araştırmalar dikkate alındığında araştırmacıların, nicel ve nitel yöntemlerin birlikte kullanıldığı karma desenleri tercih ettiği görülmektedir. Bu noktada ilk akla gelen soru araştırmanın kendisi ile araştırmanın deseni arasındaki uyumluluktur. Yürütülen araştırmada nicel ve nitel yöntemler birlikte kullanılmıştır. Araştırmada, önce nicel veriler toplanmış olup daha sonra bu verileri daha açıklayıcı hale getirmek ve detaylandırmak için nitel veriler toplanmıştır. Araştırmanın bu 
yönüyle açıklayıcı karma yöntem modelinde yürütüldüğü söylenebilmektedir. Karma yöntem araştırmaları genel anlamıyla nicel ve nitel desenlerin olumlu yönlerinin kullanılmasıyla oluşan araştırmalardır denebilmektedir (Alkan, Şimşek ve Erbil, 2019). Araştırmanın nicel boyutunda tarama (survey) yönteminden, nitel boyutunda ise görüşme yönteminden faydalanılmıştır.

\section{Araştırma grubu}

Araştırmanın çalışma grubunu 2019-2020 eğitim öğretim yılında Şanlıurfa iline bağlı resmi ve özel kurumlarda görev yapmakta olan 191 ilkokul birinci sınıf öğretmeni oluşturmuştur.

Tablo 1.

Çalışma Grubunun Cinsiyet Değişkenine Göre Dağılımı

\begin{tabular}{llc}
\hline Cinsiyet & $f$ & $\%$ \\
\hline Kadın & 119 & 37.6 \\
Erkek & 72 & 62.3 \\
\hline Toplam & 191 & 100.0 \\
\hline
\end{tabular}

Aşağıda araştırmanın nicel boyutuna katılım gösteren katılımcılar arasından gönüllülük esasına göre belirlenmiş olan ve araştırmanın nitel boyutunun oluşmasına katkı sağlayan katılımcıların cinsiyet değişkenine göre dağılımına yer verilmiştir. Araştırmanın nitel boyutunda 28 sınıf öğretmeni katılımcı olarak yer almaktadır.

Tablo 2.

Araştırmanın Nitel Boyutuna Katılan Katılımcıların Cinsiyet Değişkenine Göre Dağııımı

\begin{tabular}{lcc}
\hline Cinsiyet & $f$ & $\%$ \\
\hline Kadın & 19 & 67.8 \\
Erkek & 9 & 32.2 \\
\hline Toplam & 28 & 100.0 \\
\hline
\end{tabular}

Tablo 2 incelendiğinde araştırmanın nitel boyutunda yer alan katılımcıların cinsiyet değişkenine göre dağılımı gösterilmektedir. Buna göre araştırmanın nitel boyutunda yer alan katılımcıların yarısından fazlasının kadın sınıf öğretmenlerinden oluştuğu görülmektedir.

\section{Veri Toplama Araçları}

\section{Anket Form}

Araştırma kapsamında veri toplama aracı olarak, araştırmacılar tarafından hazırlanan anket form ve yarı yapılandırılmış görüşme formu kullanılmıştır. Ölçme araçlarının geçerlik ve güvenirlik gibi özelliklerini arttırmak amacıyla araştırmacılar tarafından anket formun hazırlanması sürecinde "Konu Alanı Ders Kitabı İncelemesi" kitapları incelenmiş ve ders kitapları genelinde bulunması gereken niteliklerin belirlenmesi amacıyla uzman görüşlerinden yararlanılarak belirtke tablosu hazırlanmıştır. Hazırlanan belirtke tablosu neticesinde;

- Ders kitaplarında fiziksel tasarım ilkeleri,

- Ders kitaplarında görsel tasarım ilkeleri,

- Ders kitaplarında alan bilgisi (Bilimsellik), 
- Ders kitaplarında kazanımlar,

- Ders kitaplarında içerik,

- Ders kitaplarında öğrenme ve öğretme süreci,

- Ders kitaplarında ölçme ve değerlendirme

Gibi alt başlıklar belirlenerek, bu alt başlıklara karşılık gelecek maddeler yazılmış ve madde havuzu oluşturulmuştur. Tartışmalar sonucunda hazırlanan alt başlıklar çerçevesinde 86 adet madde hazırlanmış ve bu maddelerden yine uzman görüşleri alınarak anket forma son halini vermek amacıyla, birbirini tekrar eden ya da uygun görülmeyen 26 sının formdan çıkarılması ile 60 maddeye düşürülmüştür. Anket formun alt boyutlarının ve alt boyutlarda bulunan maddelerin son hali ise;

- Fiziksel Tasarım Alt Boyutu (8 madde),

- Görsel Tasarım Alt Boyutu (9 madde),

- Alan Bilgisi (Bilimsellik) Alt Boyutu (11 madde),

- Kazanımlar Alt Boyutu (6 madde),

- İçerik Alt Boyutu (14 madde),

- Öğrenme ve Öğretme Süreci Alt Boyutu (8 madde),

- Ölçme ve Değerlendirme Alt Boyutu (4 madde)

Şeklindedir.

Alınan uzman görüşleri neticesinde hazırlanan anket formun $5^{\prime}$ li likert tipinde olması ve verilecek cevapların "Kesinlikle Katılmıyorum (1), Katılmıyorum (2), Kısmen Katılıyorum (3), Katılıyorum (4), Kesinlikle Katılıyorum (5)" şeklinde puanlanması kararlaştırılmıştır. Bu haliyle anket formdan alınacak en yüksek puanın 300, en düşük puanın ise 60 olacağı belirlenmiştir. Elde edilen form verilerin toplanması amacıyla ilkokul 1 . Sınıf öğretmenlerine uygulanmıştır.

Yapılan ilk uygulama sonrasında elde edilen veriler analiz edilerek ölçme aracının ne kadar tutarlı ve güvenilir olduğunun belirlenmesi amacıyla Cronbach's Alpha güvenirlik katsayısı hesaplanmıştır. Buna göre araştırma kapsamında kullanılan anket formun Cronbach's Alpha güvenirlik katsayısı .92 olarak bulunmuştur. Kullanılan formun güvenirlik katsayısı $0.90 \leq \alpha<1.00$ olduğunda, "Yüksek derecede güvenilir." Olarak tanımlanabilmektedir (Can, 2017). Buna göre yapılan araştırmada kullanılan anket formun "yüksek derecede güvenilir" olduğu söylenebilmektedir.

\section{Yarı Yapılandırılmış Görüşme Formu}

Araştırma kapsamında anket formdan elde edilen verilerin anlamlandırımasına yardımcı olabilmesi ve araştırma açısından daha derinlemesine bilgilere ulaşabilmek amacıyla araştırmacı tarafından uzman görüşleri alınarak yarı yapılandırılmış görüşsme formu oluşturulmuştur. Araştırmacı tarafından hazırlanan yarı yapılandırılmış görüşme formunun oluşturulma sürecinde, anket formun oluşturulması için taranan kaynaklar, kullanılmış ve kullanılmakta olan ders kitapları, daha önceden yapılmış olan çalışmalar gibi kaynaklar temel alınmıştır. Bu kapsamda araştırmacı tarafından uzman görüşlerine de başvurularak yarı yapılandırılmış görüşme formu için 6 adet açık uçlu soru hazırlanmıştır. Açık uçlu sorulardan bir tanesinde sonda olarak kullanılmak üzere hazırlanan 6 alt madde bulunmaktadır. Hazırlanan görüşme formuna ilişkin örnek sorular aşă̆ıdaki gibidir;

- "Okuma ve yazma öğretimi sürecinde hangi kaynaklardan faydalanıyorsunuz?"

- "1.Sınıf Türkçe Illk Okuma Yazma Kitabı'ndan eğitim-öğretim süresinde ne kadar faydalanıyorsunuz?"

- 1.Sınıf Türkçe Ilk Okuma Yazma Kitabı'nı bir öğretim materyali olarak yeterliliği konusunda neler söyleyebilirsiniz?"

\section{Verilerin Toplanması}

Araştırma kapsamında verilerin toplanması için çalışmalara 2018-2019 eğitim-öğretim yılının güz döneminde başlanmış, araştırma verileri Şanlıurfa iline bağlı okulların gezilmesi ve sadece ilkokul 1. sınıf öğretmenlerinin katılımcı olarak, gönüllülük esasına dayalı bir biçimde belirlenmesi ile toplanmıştır. Ancak verilerin toplanmasının istenilen düzeyde gerçekleşmemesi üzerine ilerleme sağlanamamış ve yeni eğitim öğretim yılında 1 . sınıf ilk okuma ve yazma ders kitabının da değişeceğinin bilinmesi üzerine elde edilen veriler araştırma kapsamında ilk uygulama olarak değerlendirilmiştir. 
2019-2020 eğitim öğretim yılının başlaması ile birlikte araştırma verilerinin toplanması süreci tekrardan başlamış, bir önceki seferden elde edinilen tecrübeler ile birlikte araştırma verileri toplanmıştır.

Anket forma yönelik verilerin toplanılmasından sonra 2. aşama olarak araştırma kapsamında hazırlanan yarı yapılandırılmış görüşme formuna yönelik verilerin toplanmasına geçilmiştir. Bu süreç kapsamında yine sadece ilkokul 1. sınıf öğretmenlerine yönelik odak grup görüşme tekniği kullanılarak araştırmanın nitel bölümüne ilişkin verilerin toplanmasına geçilmiştir.

Yarı yapılandırılmış görüşme formuna yönelik verilerin toplanması sürecine 191 sınıf öğretmeninden gönüllülük esası aranarak belirlenen 28 sınıf öğretmeni katılmıştır. Yapılan görüşmeler ortalama 1 saat sürmüştür. Görüşmeler yapılırken ortamda konuşmaların kayıt altına alındığı belirtilmiş ve katılımcılara verilerin sadece ilgili araştırma amacıyla kullanılacağı ifade edilmiştir.

\section{Verilerin Analizi}

Araştırmada anket form ile toplanan verilerin analizinde genel anlamıyla SPSS paket programdan yararlanılmıştır. Yarı yapılandırıımış görüşme formu vasıtasıyla toplanan verilerin analizinde ise betimsel analiz yönteminden faydalanılmıştır. Araştırmanın nicel boyutunda toplanan verilerin normalliğine ilişkin yapılan analiz sonuçları ve bu kapsamda elde edilen bulgular aşağıda sunulmuştur.

Tablo 3.

Anket Formdan Elde Edilen Verilerin Normallik Testi Sonuçları

\begin{tabular}{|c|c|c|c|c|c|c|}
\hline \multicolumn{7}{|c|}{ Normallik Testi } \\
\hline & \multicolumn{3}{|c|}{ Kolmogorov-Smirnov $^{\mathrm{a}}$} & \multicolumn{2}{|c|}{ Shapiro-Wilk } & \\
\hline & İstatistik & $s d$ & $\mathrm{p}$ & İstatistik & $s d$ & $\mathrm{p}$ \\
\hline Toplam Puan & .212 & 191 & .000 & .863 & 191 & .000 \\
\hline
\end{tabular}

Anket form ile toplanan verilerin analizinde öncelikle araştırma kapsamında toplanan verilerin normal dağılıp dağılmadığı yönünde analizler yapılmış ve tablo 3'e göre verilerin normal dağıım göstermediği görülmüştür. Bu doğrultuda yapılacak olan analizlerde parametrik olmayan analiz yöntemleri tercih edilmiştir. Anket formdan elde edilen genel ortalamaya yönelik verilerin analizi ve değerlendirilmesinde anket formun geliştirilmesi sürecinde oluşturulan puanlama sisteminden faydalanılmıştır.

Tablo 4.

Anket Formdan Alınan Puanların Değerlendirilmesi Bağlamında Oluşturulan Puan Aralıkları

\begin{tabular}{ll}
\hline Puan Aralıkları & Değerlendirme \\
\hline $0.00-0.99$ & Kesinlikle Yeterli Değil \\
\hline $1.00-1.99$ & Yeterli Değil \\
\hline $2.00-2.99$ & Kısmen Yeterli \\
\hline $3.00-3.99$ & Yeterli \\
\hline $4.00-5.00$ & Kesinlikle Yeterli \\
\hline
\end{tabular}

Anket formdan alınan puanların genel değerlendirilmesi bağlamında kullanılması amacıyla hazırlanan puan aralıklarına bakıldığında;

- "0.00-0.99" Kesinlikle Yeterli Değil,

- "1.00-1.99" Yeterli Değil,

- "2.00-2.99" Kısmen Yeterli,

- "3.00-3.99" Yeterli,

- "4.00-5.00" Kesinlikle Yeterli

Şeklinde olduğu görülmektedir. 
Araştırma kapsamında iki grubun elde ettiği puanlar arasındaki ilişkinin analizi için MannWhitney $U$ testi, birden fazla grubun elde ettiği puanlar arasındaki ilişkinin analiz için ise Kruskall-Wallis $\mathrm{H}$ testi kullanılmıştır.

\section{Geçerlilik ve Güvenirlilik}

Nitel araştırmalarda geçerlik kavramı birçok şekilde tanımlanabilmektedir. Nitel araştırmalarda geçerlik genel itibariyle araştırmacının süreç boyunca yansız bir şekilde araştırmaya odaklanması ve araştırılan kavramın yine yansız bir biçimde gözlemlenmesi esaslarına dayanmaktadır (Yıldırım ve Şimşek, 2008; Yıldırım, 2010). Bu kapsamda yapılan araştırmacı tarafından, araştırmanın nitel bölümünün geçerliğini artırmak amacıyla verilerin toplanması ve analiz edilmesinde objektif davranılmış, verilerin toplanılması sürecinde gözlemlenen her şey araştırma kapsamında kullanılmaya çalışılmıştır.

Yine bu kapsamda araştırmacı tarafından araştırmanın iç geçerliğini artırmaya yönelik olarak yapılan araştırmada nicel ve nitel bölümlerden elde edilen verilerin birbirini desteklediği, kuramsal anlamda bir bütünlük oluşturduğu söylenebilmektedir.

Araştırmacı tarafından ilgili araştırma süreci boyunca ele alınan temel sorunların çözümüne yönelik farklı bakış açıları ve farklı uzmanların görüşleri çerçevesinde geliştirilmiş farklı yaklaşımlar kullanılarak aşılmaya çalışılmıştır.

Araştırmanın nitel boyutunun güvenirliği bağlamında yapılan araştırma ele alınacak olursa nitel araştırma yöntemlerinin benimsendiği araştırmalarda, nicel desenler ile yürütülmüş çalışmalar gibi bir güvenirlik kavramının oluşmayacağı söylenebilmektedir (Yıldırım, 2010). Ancak yapılan araştırmada çalışmanın niteliğini artırmaya yönelik olarak güvenirlik kavramı da ele alınmış bu kapsamda yorumlayıcı paradigma temelli yaklaşım esasları benimsenmiştir.

Bu doğrultuda yapılan araştırmada en başından beri araştırmacı hem araştırmacı hem de ele aldığı sorunu farklı bakış açılarıyla gözlemlemeye çalışan bir katılımcı rolünü üstlenmiştir. Bu sayede yapılan nitel araştırmanın farklı boyutlarıyla ele alınması sağlanmıştır.

\section{Etik Kurulu İzni}

Araştırma kapsamında yayın etiğine ilişkin unsurlara araştırmacı tarafından dikkat edilmiştir. Bu kapsamda araştırma çerçevesinde verilerin toplanması amacıyla kullanılan formlar araştırmacı tarafından hazırlanmış ve uygulanması sürecinde katılımcıların gönüllülük esası dikkate alınmıştır. Yapılan araştırmanın başlangııında Milli Eğitim Bakanlığı'na bağlı Şanlıurfa il Milli Eğitim Müdürlüğü'nden 13.11.2018 tarihinde 26292541-44-E.21633384 sayı numarası ile gerekli izinler alınmış ve araştırma süreci, araştırma ve yayın etiğine uygun şekilde yürütülmüştür.

\section{Bulgular}

Araştırma kapsamında elde edilen verilerin analiz edilmesi sonrası saptanan bulgular ve bulguların yorumu aşağıda farklı başlıklar altında sunulmuştur.

\section{Nicel Bölümden Elde Edilen Bulgular}

Bu başık altında araştırma kapsamında kullanıımış olan anket form veri aracına ilişkin bulgular ve bu bulgulara ait yorumlara yer verilmiştir.

Tablo 5.

Anket Formda Bulunan Maddelerin Ortalama ve Standart Sapma Puanları 
Kitabın girişinde yer alan Türk Bayrağı, Andımız, İstiklal Marşı ve Atatürk Portresi bölümleri MEB Ders Kitapları Yönetmeliği'ne uygun olarak 3.08 1.45 hazırlanmıştır.

\begin{tabular}{|c|c|c|}
\hline $\begin{array}{l}\text { Kitapta her bölüm (Okuma-yazmaya hazırlık, Harf öğretimi, alıştırmalar, } \\
\text { ölçme ve değerlendirme) için yeteri kadar sayfa mevcuttur. }\end{array}$ & 2.49 & 1.44 \\
\hline $\begin{array}{l}\text { Kitabın sayfa düzeni ve kenar boşlukları, öğrencilerin fiziksel gelişim } \\
\text { düzeyleri için uygundur. }\end{array}$ & 2.77 & 1.37 \\
\hline $\begin{array}{l}\text { Kitap, şekil ve ebat açısından öğrencilerin fiziksel gelişim düzeylerine } \\
\text { uygundur. }\end{array}$ & 2.83 & 1.35 \\
\hline $\begin{array}{l}\text { Kitabın baskısında öğrencilerin gözlerini yormayacak ve dikkatlerini } \\
\text { dağıtmayacak nitelikte kâğıt kullanılmıştır. }\end{array}$ & 2.79 & 1.34 \\
\hline $\begin{array}{l}\text { Kitabın baskısı (Kâğıdı) öğrencilerin kurşun kalemle çalışmasına engel } \\
\text { olmayacak şekilde düzenlenmiştir. }\end{array}$ & 2.71 & 1.33 \\
\hline $\begin{array}{l}\text { Kitapta yazılar için kullanılan puntolar öğrencilerin fiziksel gelişim } \\
\text { düzeylerine uygundur. }\end{array}$ & 2.87 & 1.31 \\
\hline $\begin{array}{l}\text { Kitabın baskısı için kullanılan malzeme kaliteli ve öğrencilerin zarar } \\
\text { veremeyeceği şekilde sağlamdır. }\end{array}$ & 2.48 & 1.34 \\
\hline
\end{tabular}
veremeyeceği şekilde sağlamdır.

$$
\text { Görsel Tasarım Alt Boyutu }
$$

\begin{tabular}{|c|c|c|}
\hline Kitapta yer alan şema, şekil ve grafikler öğrencilerin seviyesine uygundur. & 2.43 & 1.28 \\
\hline $\begin{array}{l}\text { Kitapta yer alan görseller öğrencilerin görsel okuma ve görsel sunu } \\
\text { becerilerini geliştirmeye katkıda bulunmaktadır. }\end{array}$ & 2.46 & 1.39 \\
\hline $\begin{array}{l}\text { Kitapta yer alan görseller öğrencilerin hayal güçlerinin gelişimini } \\
\text { destekleyecek nitelikte hazırlanmıştır. }\end{array}$ & 2.65 & 1.27 \\
\hline $\begin{array}{l}\text { Kitaptaki metin ve görseller, öğrencilerin daha rahat çalışabilmelerine } \\
\text { olanak verecek şekilde düzenlenmiştir. }\end{array}$ & 2.72 & 1.31 \\
\hline $\begin{array}{l}\text { Kitapta önemli görülen noktalar öğrencilerin dikkatlerini çekebilecek şekilde } \\
\text { vurgulamalar (Farklı renk, daha kalın punto v.b) kullanılarak hazırlanmıştır. }\end{array}$ & 2.51 & 1.35 \\
\hline $\begin{array}{l}\text { Kitapta kullanılan renk oranı ve parlaklık düzeyi öğrencileri yormayacak } \\
\text { nitelikte hazırlanmıştır. }\end{array}$ & 2.92 & 1.34 \\
\hline $\begin{array}{l}\text { Kitaptaki görseller öğrencilerin dikkatlerini çekebilecek nitelikte renkler } \\
\text { kullanılarak hazırlanmıştır. }\end{array}$ & 2.60 & 1.25 \\
\hline $\begin{array}{l}\text { Kitabın kapak tasarımı öğrencilerin dikkatini çekebilecek şekilde } \\
\text { tasarlanmıştır. }\end{array}$ & 2.50 & 1.30 \\
\hline Kitapta görsel tasarım ilkelerine uyulmuştur ( denge, vurgu vb) & 2.81 & 1.40 \\
\hline \multicolumn{3}{|l|}{ Alan Bilgisi (Bilimsellik) Alt Boyutu } \\
\hline Kitapta yer alan bilgiler bilimsel açıdan doğrudur. & 2.76 & 1.32 \\
\hline $\begin{array}{l}\text { Kitaptaki etkinlikler ses temelli cümle yöntemi aşamaları doğrultusunda } \\
\text { (Sesi hissetme-sesi tanıma-ayırt etme- harfi yazma) ilerlemektedir. }\end{array}$ & 2.76 & 1.30 \\
\hline Okuma-yazmaya hazırlık çalışmaları öğrencilerin seviyesine uygundur. & 2.59 & 1.18 \\
\hline $\begin{array}{l}\text { Kitapta ses temelli cümle yöntemi aşamaları doğrultusunda (Sesi hissetme- } \\
\text { sesi tanıma-ayırt etme-harfi yazma...) yeteri kadar etkinlik mevcuttur. }\end{array}$ & 2.66 & 1.26 \\
\hline Kullanılan metinler öğrencilerin anlayabileceği niteliktedir. & 2.66 & 1.27 \\
\hline $\begin{array}{l}\text { Kitapta yer alan etkinlikler "Kolaydan zora, basitten karmaşığa" ilkeleri } \\
\text { gözetilerek hazırlanmıştır. }\end{array}$ & 2.89 & 1.38 \\
\hline
\end{tabular}


Kitapta yer alan etkinliklerden önce gerekli açıklamalar (yönergeler) verilmiştir.

Kitapta harf öğretimi bağlamında harflerin yazılışları ve yazılış yönlerinin gösterimi doğru bir şekilde gösterilmiştir.

2.88

Kitapta, ses temelli cümle yöntemi ile harf öğretimi açısından, harfin yazımı aşamasında öğrencilerin çalışma yapabilmeleri için yeteri kadar alan (Sırasıyla; boş alan, iki çizgi, dört çizgi-üç satır aralığı) kullanılmıştır.

Yer alan etkinlikler öğrencilerin okumaya başlaması ve okumalarını hızlandırması açısından yeterlidir.

2.42

Yer alan metinlerde Türkçe, öğrencilerin anlayabileceği şekilde kullanılmıştır.

2.80

Kazanımlar Alt Boyutu

Kitapta yer alan bilgiler müfredata ve Türkçe Dersi (1-8) Öğretim Programında yer alan kazanımlara uygundur.

Kitapta Türkçe Dersi (1-8) Öğretim Programında bulunan "Hece ve Kelimeleri Okur." Kazanımı bağlamında harf öğretiminden sonra öğrencilerin seviyesine uygun yeteri kadar hece ve kelime bulunmaktadır.

Kitapta Türkçe Dersi (1-8) Öğretim Programı bağlamında, öğrencilerin okumalar yapabilmesi için yeteri kadar basit ve kısa cümleler, kısa metinler bulunmaktadır.

Kitapta Türkçe Dersi (1-8)Öğretim Programı bağlamında öğrencilerin şiir okumaları için öğrencilerin seviyelerine uygun yeteri kadar şiir 2.38

bulunmaktadır.

Kitapta Türkçe Dersi (1-8) Öğretim Programı doğrultusunda öğrencilerin farklı yazı karakterlerinde yazılan yazıları da okumaları için, farklı yazı karakterlerinde yazılmış bölümler bulunmaktadır.

Kitapta Türkçe Dersi (1-8)Öğretim Programı bağlamında öğrencilerin dikte, bakarak yazma ve serbest yazma yapabilmeleri için yeteri kadar etkinlik ve alan bulunmaktadır.

$$
\text { İçerik Alt Boyutu }
$$

\begin{tabular}{|c|c|c|}
\hline Kitapta yer alan etkinlikler güncel tutulmuştur. & 2.38 & 1.14 \\
\hline $\begin{array}{l}\text { Kitapta yer alan etkinlikler öğrencilerin dikkatlerini çekebilecek nitelikte } \\
\text { görseller ile ilişkilendirilmiştir. }\end{array}$ & 2.26 & 1.33 \\
\hline $\begin{array}{l}\text { Ses öğretiminden sonra öğrencilerin çalışma yapabilecekleri alanlar } \\
\text { (alıştırmaya yönelik hece oluşturma, kelime oluşturma gibi) mevcuttur. }\end{array}$ & 2.67 & 1.26 \\
\hline $\begin{array}{l}\text { Ses öğretiminden sonra yer alan etkinlikler öğrencilerin önceki bilgileriyle } \\
\text { ilişkilendirilmiştir. }\end{array}$ & 2.56 & 1.25 \\
\hline $\begin{array}{l}\text { Kitapta farklı düzeylerdeki öğrenciler için de etkinlikler ve alıştırma } \\
\text { bölümleri (Harfin yazımı, hece oluşturma, kelime oluşturma..vs.) } \\
\text { mevcuttur. }\end{array}$ & 2.41 & 1.29 \\
\hline $\begin{array}{l}\text { Kitabın içerisinde öğrencilerin dikkatlerini derste tutma amacıyla çizim, } \\
\text { boyama, tamamlama gibi etkinliklere yer verilmiştir. }\end{array}$ & 2.60 & 1.36 \\
\hline $\begin{array}{l}\text { Kitapta yer alan bilgiler ve etkinlikler diğer dersler ile (Hayat Bilgisi, } \\
\text { Matematik, Resim, Müzik ..v.s) ilişkilendirilmiştir. }\end{array}$ & 2.56 & 1.33 \\
\hline $\begin{array}{l}\text { Kitapta öğrencilerin okuma alışkanlığı kazanmasını sağlayacak çalışmalar } \\
\text { mevcuttur. }\end{array}$ & 2.41 & 1.24 \\
\hline $\begin{array}{l}\text { Kitap, ilk okuma-yazma sürecini öğrenciler açısından zevkli hale } \\
\text { getirebilecek niteliktedir. }\end{array}$ & 2.46 & 1.33 \\
\hline
\end{tabular}


Metinlerde öğrencilerin noktalama işaretlerinin doğru kullanımının önemini kavrayabileceği çalışmalara yer verilmiştir.

Kitapta farklı metin türlerinden örnekler mevcuttur (Şiir, fabl, hikayev.s).

2.67

1.21

Kitaptaki metinler öğrencilerin yaratıcı düşünme, eleştirel düşünme, sorgulama yapma gibi zihinsel becerilerinin gelişimine katkı sağlayacak niteliktedir.

Kullanılan metinler günlük hayatla ilişkilendirilmiştir.

Kitapta metinlerle ilişkilendirilmiş, uygun görseller kullanılmıştır.

2.56

1.35

\begin{tabular}{|c|c|c|}
\hline \multicolumn{3}{|l|}{ Öğrenme ve Öğretme Süreci Alt Boyutu } \\
\hline Kitapta yer alan etkinlikler günlük hayatla ilişkilendirilmiştir. & 2.69 & 1.26 \\
\hline $\begin{array}{l}\text { Kitapta yer alan etkinlikler öğrencilerin bireysel farklııklarına cevap } \\
\text { verebilecek niteliktedir. }\end{array}$ & 2.34 & 1.28 \\
\hline $\begin{array}{l}\text { Kitapta okuma-yazmaya hazırlık çalışmaları bağlamında yeteri kadar etkinlik } \\
\text { bulunmaktadır. }\end{array}$ & 2.38 & 1.26 \\
\hline $\begin{array}{l}\text { Etkinlikler hazırlanırken öğrencilerin yaratıcı düşünme, eleştirel düşünme, } \\
\text { problem çözme, araştırma yapma, bilgiyi keşfetme gibi zihinsel süreçleri } \\
\text { kullanmaları dikkate alınmıştır. }\end{array}$ & 2.41 & 1.34 \\
\hline $\begin{array}{l}\text { Kitapta öğrencileri araştırma, sorgulama, yorumlama gibi becerileri } \\
\text { kullanmaya sevk edecek etkinlikler mevcuttur. }\end{array}$ & 2.31 & 1.26 \\
\hline $\begin{array}{l}\text { Kitaptaki etkinlikler öğretmenin öğrenme-öğretme sürecini } \\
\text { zenginleştirmesi bakımından esnetilebilecek nitelikte hazırlanmıştır. }\end{array}$ & 2.48 & 1.30 \\
\hline $\begin{array}{l}\text { Kitapta yer alan etkinlikler öğretmenden çok öğrencinin aktif olabileceği } \\
\text { öğretim yöntem ve tekniklerini (rol oynama, yaratıcı drama, eğitsel oyunlar } \\
\text { v.b) temel alarak hazırlanmıştır. }\end{array}$ & 2.38 & 1.32 \\
\hline $\begin{array}{l}\text { Kitap, öğretmene farklı öğretim stratejilerini uygulaması için rehberlik } \\
\text { sağlamaktadır }\end{array}$ & 2.47 & 1.32 \\
\hline \multicolumn{3}{|l|}{ Ölçme ve Değerlendirme Alt Boyutu } \\
\hline $\begin{array}{l}\text { Kitapta alternatif ölçme ve değerlendirme yöntemlerine (tanılayıcı } \\
\text { dallanmış ağaç, yapılandırılmış grid, öz değerlendirme vb.) yer verilmiştir. }\end{array}$ & 2.34 & 1.40 \\
\hline $\begin{array}{l}\text { Kitapta yer alan ölçme ve değerlendirme bölümleri öğrencilerin } \\
\text { gelişimlerini ölçebilecek niteliktedir }\end{array}$ & 2.46 & 1.39 \\
\hline $\begin{array}{l}\text { Kitapta yer alan ölçme ve değerlendirme bölümleri öğrencilerin bilişsel } \\
\text { gelişim düzeyleri dikkate alınarak hazırlanmıştır. }\end{array}$ & 2.59 & 1.36 \\
\hline $\begin{array}{l}\text { Kitapta öğrencileri farklı düşünme (Araştırma-sorgulama, problem çözme, } \\
\text { yaratıcı düşünme, eleştirel düşünme v.b) stillerini kullanmaya yöneltecek } \\
\text { ölçme ve değerlendirme etkinliklerine yer verilmiştir. }\end{array}$ & 2.48 & 1.38 \\
\hline
\end{tabular}

Araştırma kapsamında anket form genelinde toplanan veriler incelendiğinde genel itibariyle maddelerden alınan puanların ortalamalarının birbirine yakın olduğu ve yine genel itibariyle "Kısmen Katılıyorum" seçeneğine ve "Katılmıyorum" seçeneğine yakın cevapların verildiği söylenebilmektedir. Buradan hareketle sınıf öğretmenlerinin 1. Sınıf Türkçe İlk Okuma ve Yazma Ders Kitabı'na yönelik olarak, ders kitabını "Kısmen Yeterli" olarak gördükleri söylenebilmektedir. 
Tablo 6.

Anketin Alt Boyutlarına Illişkin Ortalama ve Standart Sapma Değerleri

\begin{tabular}{lcc}
\hline Alt Boyutlar & $\bar{x}$ & $S S$ \\
\hline Fiziksel Tasarım & 2.73 & 1.17 \\
Görsel Tasarım & 2.67 & 1.15 \\
İçerik & 2.56 & 1.11 \\
Alan Bilgisi (Bilimsellik) & 2.69 & 1.12 \\
Kazanımlar & 2.46 & 1.14 \\
Öğrenme ve Öğretme Süreci & 2.43 & 1.13 \\
Ölçme ve Değerlendirme & 2.47 & 1.25 \\
\hline
\end{tabular}

Tablo 6'ya bakıldığında araştırmacı tarafından hazırlanmış olan anket forma ilişkin alt boyutlardan alınan ortalama puanlar ve puanların standart sapma değerleri görülmektedir. Buradan hareketle ilgili tablo incelendiğinde; sınıf öğretmenlerinin Birinci Sınıf Türkçe İlk Okuma ve Yazma Kitabı'nın fiziksel tasarım, görsel tasarım ve alan bilgisi(bilimsellik) alt boyutlarına ilişkin uygulanmış olan anketten daha fazla puan aldıkları, öğrenme ve öğretme süreci, kazanımlar, ölçme ve değerlendirme ve içerik alt boyutlarından ise daha az puan aldıkları görülmektedir. Buradan hareketle sınıf öğretmenlerinin 1. Sınıf Türkçe illk Okuma ve Yazma Ders Kitabı'na ilişkin görüşlerinin alt boyutlar çerçevesinde "Kısmen Yeterli" puan aralığına denk geldiği söylenebilmektedir. Buna rağmen sınıf öğretmenlerinin ilgili kitaba ilişkin en yeterli gördükleri bölümlerin ders kitabının fiziksel tasarımı ve ders kitabının görsel tasarımı olduğu görülmektedir.

\section{Cinsiyet Değişkenine iliş̧kin Bulgular}

Araştırma kapsamında cinsiyet değişkeninin öğretmenlerin Birinci Sınıf ilk okuma ve yazma kitabı hakkındaki görüşlerini anlamlı şekilde etkileyip etkilemediğini görmek amacıyla Mann-Whitney $\mathrm{U}$ testi yapılmıştır. Elde edilen bulgular tablolaştırıımış ve yorumlanmıştır.

Tablo 7.

Cinsiyet Değişkenine Yönelik Yapılan Mann-Whitney U Testi Sonuçları

\begin{tabular}{llrrrr}
\hline Grup & $N$ & Sıra Ortalaması & Sıra Toplamı & $U$ & $p$ \\
\hline Kadın & 119 & 93.77 & 11158 & & 0.47 \\
Erkek & 72 & 99.69 & 7177 & & \\
\hline
\end{tabular}

Tablo 7 incelendiğinde; "Sınıf öğretmenlerinin ilkokul birinci sınıf ilk okuma ve yazma kitabı hakkındaki görüşleri cinsiyet değişkenine göre anlamlı bir şekilde farklılaşmakta mıdır?" problemine yönelik bulgular görülmektedir. Buna göre öğretmenlerin ders kitapları hakkındaki görüşlerinde cinsiyet değişkeni açısından anlamlı bir fark görülememiştir $(p>0.05)$. Tablo incelenmeye devam edildiğinde anlamlı bir farklılık olmamasına karşın erkek öğretmenlerin, kadın öğretmenlere göre anket formdan daha yüksek puanlar aldıkları söylenebilmektedir.

\section{Yaş Değişkenine ilişkin Bulgular}

Araştırma kapsamında yaş değişkeninin öğretmenlerin birinci sınıf ilk okuma ve yazma kitabı hakkındaki görüşlerini anlamlı şekilde etkileyip etkilemediğini görmek amacıyla Kruskall-Wallis $\mathrm{H}$ testi yapılmıştır. Elde edilen bulgular tablolaştırılarak yorumlanmıştır.

Tablo 8.

Yaş Değişkenine Yönelik Yapılan Kruskall-Wallis H Testi Sonuçları

\begin{tabular}{llcllll}
\hline Grup & $N$ & Sira Ortalaması & $s d$ & $X^{2}$ & $p$ & Anlamlı Fark \\
\hline $22-26$ & 89 & 99.84 & 4 & 2.679 & 0.613 & Yok \\
$27-31$ & 81 & 93.83 & & & &
\end{tabular}




$\begin{array}{lll}32-36 & 11 & 75.27 \\ 37-41 & 6 & 111.75 \\ 42-46 & 4 & 87.75\end{array}$

Tablo 8 incelendiğinde; "Sınıf öğretmenlerinin ilkokul birinci Sınıf ilk okuma ve yazma kitabı hakkındaki görüşleri yaş değişkenine göre anlamlı bir şekilde farklılaşmakta mıdır?" problemine yönelik bulgular görülmektedir. Buna göre öğretmenlerin ders kitapları hakkındaki görüşlerinde yaş değişkeni açısından anlamlı bir fark görülememiştir ( $p>0.05)$. Tablo incelenmeye devam edildiğinde anlamlı bir farklıık olmamasına karşın 32-36 yaş aralığındaki öğretmenlerin anket formdan diğer yaş aralıklarındaki öğretmenlere göre daha düşük puanlar aldıkları, 37-41 yaş aralığındaki öğretmenlerin ise daha yüksek puanlar aldıkları görülmektedir.

\section{Mesleki Deneyim Değişkenine ilişkin Bulgular}

Araştırma kapsamında mesleki deneyim değişkeninin öğretmenlerin birinci Sınıf ilk okuma ve yazma kitabı hakkındaki görüşlerini anlamlı şekilde etkileyip etkilemediğini görmek amacıyla KruskallWallis $\mathrm{H}$ testi yapılmıştır. Elde edilen bulgular tablolaştırılarak yorumlanmıştır.

Tablo 9.

Mesleki Deneyim Değişkenine Yönelik Yapılan Kruskall-Wallis H Testi Sonuçları

\begin{tabular}{|c|c|c|c|c|c|c|}
\hline Grup & $N$ & Sıra Ortalaması & $s d$ & $x^{2}$ & $p$ & Anlamlı Fark \\
\hline $0-1 Y_{\prime}$ & 72 & 93.95 & 4 & 9.37 & 0.04 & 2-4 YII-8-10 \\
\hline 2-4 Yıl & 76 & 100.62 & & & & Yıl \\
\hline 5-7 Y Yl & 28 & 96.68 & & & & \\
\hline 8-10 YII & 6 & 35.02 & & & & \\
\hline 10 Yıl ve Üst & 9 & 98.11 & & & & \\
\hline
\end{tabular}

Tablo 9 incelendiğinde; "Sınıf öğretmenlerinin ilkokul birinci sınıf ilk okuma ve yazma kitabı hakkındaki görüşleri mesleki deneyim değişkenine göre anlamlı bir şekilde farklılaşmakta mıdır?" problemine yönelik bulgular görülmektedir. Buna göre tablo incelendiğinde mesleki deneyim ile öğretmenlerin anket formdan aldıkları puanlar arasında anlamlı bir farklılık olduğu görülmektedir. Bunun sonucunda ilgili anlamlı farklılığı bulmak amacıyla Mann-Whitney $U$ testi yapılmış ve 2-4 yıl mesleki deneyime sahip öğretmenler ile 8-10 yıl mesleki deneyime sahip öğretmenler arasında 2-4 yıl mesleki deneyime sahip öğretmenler lehine anlamlı bir farklılık bulunmuştur $\left(x^{2}=9.37, p<0.05\right)$.

\section{Kurumun Bulunduğu Yerleşim Birimi Değişkenine ilişkin Bulgular}

Araştırma kapsamında öğretmenlerin görev yapmakta oldukları kurumun bulunduğu yerleşim birimi değişkeninin öğretmenlerin birinci sınıf ilk okuma ve yazma kitabı hakkındaki görüşlerini anlamlı şekilde etkileyip etkilemediğini görmek amacıyla Kruskall-Wallis $\mathrm{H}$ testi yapılmıştır. Elde edilen bulgular tablolaştırılarak yorumlanmıştır.

Tablo 10.

Kurumun Bulunduğu Yerleşim Birimi Değişkenine Yönelik Yapılan Kruskall-Wallis H Testi Sonuçları

\begin{tabular}{llrllll}
\hline Grup & $N$ & Sıra Ortalaması & $s d$ & $X^{2}$ & $p$ & Anlamlı Fark \\
\hline Köy & 60 & 105.63 & 3 & 8.327 & 0.04 & Köy \\
Kasaba & 60 & 101.65 & & & & $\begin{array}{l}\text { Büyükşehir } \\
\text { Köy-Şehir }\end{array}$ \\
Şehir & 23 & 77.59 & & & & \\
Büyükşehir & 48 & 82.07 & & & & \\
\hline
\end{tabular}

Tablo 10 incelendiğinde; "Sınıf öğretmenlerinin ilkokul birinci sınıf ilk okuma ve yazma kitabı hakkındaki görüşleri çalışmakta oldukları kurumun bağlı olduğu yerleşim birimi değişkenine göre 
anlamlı bir şekilde farklılaşmakta mıdır?" problemine yönelik bulgular görülmektedir. Buna göre tablo incelendiğinde öğretmenlerin çalışmakta oldukları kurumun bağlı olduğu yerleşim birimi değişkeni ile öğretmenlerin anket formdan aldıkları puanlar arasında anlamlı bir farklılık görünmektedir. Bunun sonucunda ilgili anlamlı farklılığı bulmak amacıyla mann-whitney u testi yapıımış ve çalıştıkları kurum köy yerleşim birimine bağlı öğretmenler ile, çalıştığı kurum şehir ve büyükşehir yerleşim birimine bağlı öğretmenler arasında, köy yerleşim birimine bağlı kurumlarda çalışan öğretmenler lehine anlamlı bir farklılık bulunmuştur $\left(x^{2}=8.32, p<0.05\right)$.

\section{Mezuniyet Durumu Değişkenine ilişkin Bulgular}

Araştırma kapsamında öğretmenlerin mezuniyet durumu değişkeninin öğretmenlerin birinci sınıf ilk okuma ve yazma kitabı hakkındaki görüşlerini anlamlı şekilde etkileyip etkilemediğini görmek amacıyla Kruskall-Wallis $\mathrm{H}$ testi yapılmıştır. Elde edilen bulgular tablolaştırılarak yorumlanmıştır.

Tablo 11.

Mezuniyet Durumu Değişkenine Yönelik Yapılan Kruskall-Wallis H Testi Sonuçları

\begin{tabular}{lrcllll}
\hline Grup & $N$ & Sıra Ortalaması & $s d$ & $X^{2}$ & $p$ & Anlamlı Fark \\
\hline Yüksekokul & 17 & 117.91 & 2 & 5.606 & 0.06 & Yok \\
Lisans & 153 & 92.53 & & & & \\
Yüksek & 21 & 77.59 & & & & \\
Lisans & & & & & & \\
\hline
\end{tabular}

Tablo 11 incelendiğinde; "Sınıf öğretmenlerinin ilkokul birinci sınıf ilk okuma ve yazma kitabı hakkındaki görüşleri mezuniyet durumu değişkenine göre anlamlı bir şekilde farklılaşmakta mıdır?" problemine yönelik bulgular görülmektedir. Buna göre tablo incelendiğinde öğretmenlerin mezuniyet durumu değişkeni ile öğretmenlerin anket formdan aldıkları puanlar arasında anlamlı bir farklılık görülmemiştir $(p>0.05)$. Buna rağmen tablo incelenmeye devam edildiğinde, anket formdan en yüksek puanı yüksekokul mezunu öğretmenlerin aldığı, en düşük puanı ise yüksek lisans mezunu öğretmenlerin aldığı görülmektedir.

\section{Nitel Bölümden Elde Edilen Bulgular}

Bu başlık altında araştırma kapsamında kullanıımış olan yarı yapılandırıımış görüşme formu veri toplama aracından elde edilen bulgular ve bulgulara ilişkin yorumlara yer verilmiştir. Bu doğrultuda araştırmaya katılan 191 öğretmenden gönüllülük esasına dayalı olarak 28'ine yüz yüze ve odak grup görüşme teknikleri kullanılarak araştırmacı tarafından hazırlanan sorular sorulmuş, elde edilen bulgular frekans ve yüzde kullanılarak tablolaştırılmıştır.

\section{"Okuma-Yazma Sürecinde Hangi Kaynaklardan Faydalanıyorsunuz?" Sorusuna ilişskin Bulgular}

Sınıf öğretmenlerine bu bölümde okuma-yazma sürecinde hangi kaynaklardan faydalandıkları sorulmuş, elde edilen bulgular tablolaştırılmış ve yorumlanmıştır

Tablo 12.

"Okuma-Yazma Sürecinde Hangi Kaynaklardan Faydalanıyorsunuz?" Sorusuna ilişkin Bulgular

\begin{tabular}{lll}
\hline Cevaplar & $f$ & $\%$ \\
\hline Yalnızca DersKitabı & 10 & 35.71 \\
Etkileşimli Tahta veUygulamaları & 8 & 28.57 \\
Okuma Setleri & 6 & 21.42 \\
Yardımcı Kaynak Kitaplar & 4 & 14.28 \\
\hline Toplam & 28 & 100 \\
\hline
\end{tabular}

Tablo 12 incelendiğinde, sınıf öğretmenlerinin "Okuma-yazma sürecinde hangi kaynaklardan faydalanıyorsunuz?" sorusuna ilişkin verdikleri yanıtlar görülmektedir. Öğretmenlerin tamamı ders 
kitaplarından okuma-yazma sürecinde faydalandıklarını belirmişlerdir. Buna ek olarak, öğretmenlerin 8'i etkileşimli tahta ve buna yönelik uygulamalardan yararlandıklarını belirtmişlerdir.

K4: "Süreç içerisinde ders kitaplarından oldukça fazla yararlanıyoruz. Tabii ki bazı durumlarda yetersiz kalabiliyor, ben genelde sınıfımda etkileşimli tahtadan yararlanıyorum. Seslerin hissettirilmesi, sesin tanıtılması aşamalarında videolardan, görsellerden faydalanıyorum..."

Öğretmenlerden $10^{\prime}$ u okuma-yazma sürecinde yalnızca ders kitaplarından faydalandıklarını, bunun yanında farklı kaynaklardan yararlanmadıklarını belirtmişlerdir.

K22: “ Okuma-yazma çalışmalarında ders kitaplarını kullanıyorum. Buna yönelik herhangi bir başka şeyden yararlanmıyorum. Zaten şartlar gereği akıllı tahta, bilgisayar gibi şeyleri kullanmam mümkün olmuyor. Okuma ve yazma işi bittikten sonra tabii ki faydalandığım şeyler var ama başlangıçta sadece ders kitabı diyebilirim..."

Okuma-yazma sürecinde faydalanılan kaynaklar ile ilgili 6 sınıf öğretmeni okuma setlerinden, 4 sınıf öğretmeni de diğer yardımcı kaynak kitaplardan faydalandıklarını belirtmişlerdir.

K13: "Okuma-yazmada özellikle yazma konusunda kitapta yeterli alan yok. Bazı öğrenciler için yeterli oluyor, bazı öğrenciler için hiç yeterli olmuyor. Bunun için bazı kitaplar var, alıştırma v.b. için, ben onlardan kullanıyorum ihtiyaç duyduğum zaman..."

K7: "Süreç içerisinde ben genelde ilk aşamayı atlattıktan sonra hece ve kelimeye ulaşma açısından farklı okuma setleri kullanıyorum. Renkli heceler içeriyor, çocukların daha çabuk heceye ve kelimeye ulaşmasında işe yarıyor..."

\section{"1.Sınıf Türkçe ilk Okuma Yazma Kitabı'ndan Eğitim-Öğretim Süresince Ne Kadar Faydalanıyorsunuz?" Sorusuna iliş̧kin Bulgular}

Sınıf öğretmenlerine bu bölümde okuma-yazma sürecinde birinci sınıf Türkçe ilk okuma yazma kitabından ne kadar faydalandıkları sorulmuş, bu soruya ilişkin verilen cevaplar yüzde ve frekans kullanılarak tablolaştırılmıştır.

Tablo 13.

"Birinci Sınıf Türkçe Illk Okuma Yazma Kitabı'ndan Eğitim-Öğretim Süresince Ne kadar faydalanıyorsunuz?" Sorusuna ilişskin Bulgular

\begin{tabular}{lll}
\hline Cevaplar & $f$ & $\%$ \\
\hline Oldukça Fazla Faydalanıyorum & 12 & 42.85 \\
Tüm Süreç Boyunca & 8 & 28.57 \\
Ders Saatinin Yarısı Kadar & 8 & 28.57 \\
\hline Toplam & 28 & 100 \\
\hline
\end{tabular}

Tablo 13 incelendiğinde, sınıf öğretmenlerinin "Birinci Sınıf Türkçe Illk Okuma Yazma Kitabı'ndan eğitim-öğretim süresince ne kadar faydalanıyorsunuz?" sorusuna ilişkin verdikleri yanıtlar görülmektedir. Tabloya göre sınıf öğretmenlerinin yarısından fazlası Birinci Sınıf Türkçe illk Okuma Yazma Kitabı'nı neredeyse sürecin tamamında kullanmaktadırlar. Öyle ki; öğretmenlerin 12'si bu soruya ilişkin "Oldukça fazla kullanıyorum." Cevabını, 8' $i$ ise "Tüm süreç boyunca" cevabını vermişlerdir. Öğretmenlerden yine 8'i ise "Ancak bir dersin yarısı kadar." Yanıtını vermişlerdir.

K1: "Kitabı tabii ki oldukça fazla kullanıyoruz. Dersi kitap üstünden yürütüyoruz. Planlar, programlar var tabii ama kitaptan ilerlediğimiz zaman da oldukça fazla diyebilirim..."

K18: "Ben ders kitabını kullanıyorum evet ama mesela 2 dersim varsa ancak 1'inde kullanıyorum. Diğerinde daha çok farklı etkinliklere yöneliyorum. Şöyle diyeyim; mesela bir harfi öğreteceğim, önce videodan sesi tanıtma çalışmaları yapıyorum, bu da bir ders kadar sürüyor diyebilirim. Sonra diğer derste kitaptan işleyebilirim..."

K4: "Süreçte genelde kitap kullanıyorum zaten. Kitaptan gidiyorum..." 


\section{"1.Sınıf Türkçe Illk Okuma Yazma Kitabı'nın Bir Öğretim Materyali Olarak Yeterliliği Konusunda Neler Söyleyebilirsiniz?" Sorusuna ilişkin Bulgular}

Sınıf öğretmenlerine bu bölümde Birinci Sınıf Türkçe İlk Okuma Yazma Kitabı́nın bir öğretim materyali olarak düşünüldüğünde yeterliliğini değerlendirmeleri istenmiştir. Bu soruya ilişkin bulgular analiz edilmiş, frekans ve yüzde kullanılarak tablolaştırılmıştır.

Tablo 14.

“Birinci Sınıf Türkçe ilk Okuma Yazma Kitabı'nın Bir Öğretim Materyali Olarak Yeterliliği Konusunda Neler Söyleyebilirsiniz?" Sorusuna ilişskin Bulgular

\begin{tabular}{lll}
\hline Cevaplar & $f$ & $\%$ \\
\hline Kısmen Yeterli & 11 & 39.28 \\
Yeterli Görüyorum & 9 & 32.14 \\
Yeterli Değil & 8 & 28.57 \\
\hline Toplam & 28 & 100 \\
\hline
\end{tabular}

Tablo 14'e bakıldı̆ıında, sınıf öğretmenlerinin “Birinci Sınıf Türkçe illk Okuma Yazma Kitabı́nın Bir Öğretim Materyali Olarak Yeterliliği Konusunda Neler Söyleyebilirsiniz?" sorusuna ilişkin verdikleri yanıtlar görülmektedir. Tabloya göre sınıf öğretmenlerinin yarısına yakını 1. Sınıf Türkçe illk Okuma Yazma Ders Kitabı'nı "Kısmen Yeterli” olarak görmektedir. Bunun yanında öğretmenlerin 9'u ders kitabını yeterli görürken, 8'i de ders kitabının yeterli olmadığını dile getirmişlerdir.

K23: "Ben ders kitabının yeterli olduğunu düşünmüyorum. Çünkü farklı şeyler kullanmak durumunda kalıyoruz, tabii ki materyal v.b. hazırlayacağız ama bazen özellikle sınıf geneli düşünülürse, geride olan öğrenciler var, bu öğrencilere yeterli gelmiyor..."

K12: "Kitap genel anlamda yeterli diyebilirim. Farklı türden etkinlikler var, sadece bazı alanları biraz eksik, mesela yeteri kadar yazı alanı yok, yeteri kadar yazma çalışması yapılamıyor, kısmen yeterli diyebilirim..."

K20: "Ben ders kitabının iyi ve yeterli olduğunu düşünüyorum. Resimleri, çalışmaları, metinleri yeterli diye düşünüyorum..."

\section{"Ben Bir Öğretmen Olarak Kitabın ... Eksik/Yetersiz Buldum Bence .....Olmalıydı ." Dediğiniz Bölümler Var Mıdır? Var ise Hangileridir?" Sorusuna ilişkin Bulgular}

Sınıf öğretmenlerine bu bölümde Birinci Sınıf Türkçe İlk Okuma Yazma Kitabı́nın kendilerine göre eksik ya da yetersiz kısımları olup olmadığı sorulmuş bu konuda eksik gördükleri yerler var ise bunların hangileri olduğu sorusu yöneltilmiştir. Bu soruya ilişkin bulgular analiz edilmiş, frekans ve yüzde kullanılarak tablolaştırılmıştır.

Tablo 15.

"Ben Bir Öğretmen Olarak Kitabın ... Eksik/Yetersiz Buldum Bence .....Olmalıydı ." Dediğiniz Bölümler Var Mıdır? Var Ise Hangileridir?" Sorusuna ilişskin Bulgular

\begin{tabular}{lll}
\hline Cevaplar & $f$ & $\%$ \\
\hline Hece ve Kelimeye Geçiş & 10 & 35.71 \\
Çalışma Alanları & 7 & 25.00 \\
Metinler & 5 & 17.85 \\
Somutlaştırma & 4 & 14.28 \\
Yeterli & 2 & 7.14 \\
\hline Toplam & 28 & 100 \\
\hline
\end{tabular}

Tablo 15'e bakıldığında, sınıf öğretmenlerinin “Ben bir öğretmen olarak kitabın ... eksik/yetersiz buldum bence .....olmalıydı ." dediğiniz bölümler var mıdır? Var ise hangileridir?" sorusuna ilişkin 
verdikleri yanıtlar görülmektedir. Tabloya göre sınıf öğretmenlerinin yarısına yakını ders kitabında bulunan hece ve kelimeye geçiş çalışmalarını yetersiz bulmaktadır.

K6: " Kitapta benim gördüğüm, yani zorlandı̆̆ım kısımlar genelde heceye geçiş çalışmaları, kelime türetme, kelimeye ulaşma çalışmaları oluyor. Bu noktada biraz sıkıntı yaşıyoruz..."

Yine sınıf öğretmenlerinin 7'si çalışma alanlarını, 5'i metinleri, 4'ü ders kitabının somutlaştırma özelliğini yetersiz bulmaktadır. Bunların yanında 2 sınıf öğretmeninin de ders kitabının yeterli olduğunu söylediği görülmektedir.

K19: " Kitabın geneli aslında iyi ama bence kitapta yazmaya yönelik oldukça az alan var. Çizgili üzerinden geçilebilecek, etkinlikler yapılabilecek az alan var..."

K15: "Kitapta metin kısımlarının yeterli olmadığını düşünüyorum. Her bölümün sonunda genelde metinler var ama bu metinler ya kısa geliyor ya da metinleri yazmak için yeterli olan olmuyor..."

K3: "Ben ders kitabında özellikle seslerin somutlaştırılması, resimleştirilmesi konusunu önemsiyorum. Çünkü çocuklara bu konuda sadece de kitap kullandığım için, hissettirmede sorunlar yaşıyorum bazen...

K20: "Bence kitap ve kullanımı yeterli."

“Birinci Sınıf Türkçe Ilk Okuma Yazma Kitabı'nda "Tam Olarak Yeterli/ Oldukça Tatmin Edici" Olarak Nitelendirebileceğiniz Bölümler Hangileridir? Niçin?" Sorusuna ilişskin Bulgular

Sınıf öğretmenlerine bu bölümde Birinci Sınıf Türkçe İlk Okuma Yazma Kitabı́nın kendilerine göre yeterli ya da tatmin edici olarak nitelendirebildikleri alanlar olup olmadığı sorulmuştur. Bu soruya ilişkin bulgular analiz edilmiş, frekans ve yüzde kullanılarak tablolaştırılmıştır.

Tablo 16.

"Birinci Sınıf Türkçe Illk Okuma Yazma Kitabı'nda "Tam Olarak Yeterli/ Oldukça Tatmin Edici" Olarak Nitelendirebileceğiniz Bölümler Hangileridir? Niçin?" Sorusuna iliş̧kin Bulgular

\begin{tabular}{lll}
\hline Cevaplar & $f$ & $\%$ \\
\hline Sesi Tanıma- Hissetme & 13 & 46.42 \\
Görseller & 9 & 32.14 \\
Tasarımsal Özellikler & 6 & 21.42 \\
\hline Toplam & 28 & 100 \\
\hline
\end{tabular}

Tablo 16 incelendiğinde, sınıf öğretmenlerinin "Birinci Sınıf Türkçe Illk Okuma Yazma Kitabı’nda "tam olarak yeterli/ oldukça tatmin edici" olarak nitelendirebileceğiniz bölümler hangileridir? Niçin?" sorusuna ilişkin verdikleri yanıtlar görülmektedir. Tabloya göre 13 sınıf öğretmeni kendileri açısından sesi tanıma ve hissettirmeye yönelik çalışmaların olduğu bölümleri, 9 sınıf öğretmeni de ders kitabında bulunan görselleri tam olarak yeterli görmüşlerdir.

K10: “Ders kitabında ben sesi tanıtmaya yönelik etkinliklerin yeterli olduğunu söyleyebilirim. Yine burada kullanılan görseller, hissettirmeye yönelik çalışmalar, bunlar tam olarak yeterli benim için. Kullanırken ben genelde bu alanlarda hiçbir sorun yaşamadım..."

Sınıf öğretmenlerinin 6 'sı ise kendileri açısından kitabın tasarımsal özelliklerini yeterli görmüşlerdir.

K11: “ Kitapta büyüklük, küçüklük, harflerin uygunluğu, resimlerin uygunluğu bu tür noktaların ben oldukça yeterli olduğunu düşünüyorum. Öğrenci seviyesine uygun ve iyi hazırlanmış..."

\section{"Siz Olsaydınız Bir Öğretim Materyali Olarak Nasıl Bir Birinci Sınıf ilk Okuma ve Yazma Kitabı Tasarlardınız?" Sorusuna ilişkin Bulgular}

Sınıf öğretmenlerine bu bölümde nasıl bir ilk okuma ve yazma kitabı tasarlamak istedikleri sorulmuştur. Soruya verilen cevaplar analiz edilmiş, frekans ve yüzde kullanılarak tablolaştırılmıştır. 
Tablo 17.

"Siz Olsaydınız Bir Öğretim Materyali Olarak Nasıl Bir Birinci Sınıf ilk Okuma ve Yazma Kitabı Tasarlardınız?" Sorusuna ilișkin Bulgular

\begin{tabular}{lll}
\hline Cevaplar & $f$ & $\%$ \\
\hline Hazırlık Kısmı Ön Planda & 11 & 46.42 \\
Çalışma Alanları Ön Planda & 8 & 32.14 \\
Tasarımsal Özellikler Ön Planda & 6 & 21.42 \\
Mevcut Kitap Gibi & 3 & 10.71 \\
\hline Toplam & 28 & 100 \\
\hline
\end{tabular}

Tablo 17'ye bakıldığında, öğretmenlerin "Nasıl bir ilk okuma yazma kitabı tasarlamak isterdiniz?" sorusuna yönelik verdikleri cevaplar görülmektedir. Buna göre 11 sınıf öğretmeni, hazırlık kısımlarının daha ön planda bir ilk okuma yazma kitabı tasarlamak istediklerini söylemişlerdir.

K28: "Asıında ben daha çok okuma yazmaya hazırlık çalışmaları gibi kısımlar barındıran, çocukların daha çok eğlenebileceği, onlara dersi daha çok sevdirecek bir kitap tasarlamak isterdim."

Öğretmenlerden 8'i çalışma alanlarının ön planda olduğu, 6'sı tasarımsal özelliklerin daha ön planda olduğu bir kitap tasarlamak isterken, 3 öğretmenin de mevcut kitap gibi bir kitap tasarlamak istediği görülmüştür.

K3: "Kitabı ben tasarlıyor olsam...Ben tasarlıyor olsam daha kaliteli görseller kullanırdım. Her anlamda. Daha detaylı ve çocuklar tarafından daha çabuk anlaşılabilecek görsellerin olduğu bir kitabım olurdu..."

K20: "Ben kullandığımız kitaba benzer bir kitap hazırlardım..."

K19: "Benim tasarımında katkıda bulunduğum ders kitabında daha çok yazı yazmak için alanlar olurdu sanırım. Kitapta, az önce de bahsettik, çok fazla alan bulunmuyor bu açıdan..."

\section{Tartışma ve Sonuç}

Bu bölümde araştırma genelinde elde edilen bulguların yorumlanması neticesinde ortaya çıkan sonuçlar ele alınmış ve ilgili literatür taranarak, farklı araştırmaların sonuçları ile tartışıımıştır. Bölüm sonunda araştırmacı tarafından ilgili alanyazına katkı sağlayabileceği düşünülen bir takım öneriler sunulmuştur.

\section{Nicel Bölüme iliş̧kin Sonuçlar ve Tartışma}

Bu bölümde araştırmanın nicel bölümden elde edilen sonuçlar sunulmuş ve ilgili literatür çerçevesinde tartışıımıştır.

Araştırmanın nicel boyutuna ilişkin sonuçlara bakıldığında öğretmenlerin anket forma verdikleri yanıtların ortalama puanlarının birbirine yakın olduğu görülmektedir. Puanlar incelendiğinde sınıf öğretmenlerinin Birinci Sınıf Türkçe Illk Okuma ve Yazma Ders Kitabı'na ilişkin uygulanan anketten aldıkları puanların ortalama olarak "Kısmen Yeterli" seçeneğine daha yakın olduğu görülmüştür. Bu doğrultuda sınıf öğretmenlerinin nitel bölümden elde edilen bulgular çerçevesinde öğrenme ve öğretme sürecinde, ilk okuma ve yazma öğretimi bağlamında genel itibariyle ders kitabından faydalandıkları ve kitabın da eksik olarak görülen bölümlerinin bu sonucun çıkmasında etkili olduğu sonucuna ulaşılabilmektedir. Lalău (2014)'nun da yaptığı araştırmada sınıf öğretmenleri ilkokul ders kitapları bağlamında, ders kitabının uygulanmakta olan öğretim programı çerçevesi açısından kısmen yeterli, yaklaşık olarak yeterli gördükleri ortaya konmuştur. Yapılan araştırmada bu sonuçların nedeni olarak, içeriğin bazı bölümlerinin programdaki ögeleri kapsamadığı, ders kitabının bazı bölümlerinin içerikle tam olarak örtüşmediği gibi gerekçeler öne sürülmüştür. Yapılan başka bir araştırmada ilköğretim birinci kademede okutulan matematik ders kitaplarının öğretmen görüşlerine göre incelenmesi amaçlanmış ve araştırma sonucuna göre de öğretmenlerin ders kitabını genel itibariyle yeterli ve kısmen yeterli olarak gördükleri ortaya konmuştur (Taşdemir, 2011). Araştırmada böyle bir sonuca ulaşıımasının nedeni olarak ise öğretmenlerin ilgili ders kitabına yönelik bazı noktaları yetersiz olarak gördükleri belirtilmiştir. 
Nicel bölümden elde edilen bulgular incelenmeye devam edildiğinde sınıf öğretmenlerinin ders kitabında bulunan etkinliklerin günlük hayatla ilişkilendirilmesine yönelik maddeye "kısmen yeterli" cevabını verdikleri görülmüştür. Güven (2010) de Hayat Bilgisi ders ve öğrenci çalışma kitabını öğretmen görüşleri çerçevesinde incelediği araştırmasında, öğretmenlerin ders kitabında bulunan etkinliklerin günlük hayatla ilişkilendirilmesi yönünde bazı eksiklikler olduğu sonucuna ulaşmıştır. Incelenen araştırmada elde edilen bu sonuç yapılan çalışmayı destekler niteliktedir. Yine Hayat Bilgisi ders kitabına ilişkin öğretmen görüşlerinin incelendiği bir yüksek lisans tez çalışmasında da öğretmenlerin ders kitabında bulunan mevcut etkinliklerin günlük hayatla ilişkilendirilmesi noktasını yetersiz buldukları sonucuna ulaşılmıştır (Yıldııım, 2006). Taşdemir (2011) de yaptığı araştırmada öğretmen görüşlerine bağlamında incelediği ders kitabında bulunan etkinliklerin günlük hayatla ilişkilendirilmesi noktasında, öğretmenlerin ders kitabını bu yönüyle yeterli olarak gördükleri sonucuna ulaşmıştır. Sosyal bilgiler ders kitabının öğretmen görüşleri bağlamında değerlendirildiği bir araştırmada da, öğretmenler ders kitabının içeriksel anlamda kısmen olumlu, yani yeterli olduğunu belirtmişlerdir (Taş, 2007).

Ders kitabında bulunan bilgilerin, öğrencilerin gördüğü diğer dersler ve kullanılan diğer ders kitapları ile ilişkilendirilmesine yönelik bulgular incelendiğinde sınıf öğretmenlerinin bu maddeye de "kısmen yeterli" cevabını verdikleri ortaya konulmuştur. Ders kitabında bulunan etkinliklerin diğer dersler ve aynı zamanda günlük hayatla ilişkilendirilmesi, öğrencilerin bireysel gereksinimleri ve öğrenme-öğretme yaşantıları dikkate alındığında oldukça önemli bir rolü üstlenmektedir. İncelenen bir araştırmada sınıf öğretmenlerinin, Hayat Bilgisi ders kitabında bulunan etkinliklerin diğer dersler ile ilişkilendirilmesine yönelik olumsuz görüşlere sahip olduğu, bu noktada bir takım eksiklikler gözlemledikleri sonuçlarına ulaşılmıştır, incelenen araştırmada görülen bu sonuç yapılan araştırmayı bu yönüyle destekler niteliktedir (Güven, 2010).

Yapılan araştırmada ilgili ders kitabında bulunan etkinlik ve metinlerin öğrencileri eleştirel düşünme, sorgulama yapma, yaratıcı düşünme gibi zihinsel becerilere sevk etme açısından sınıf öğretmenlerinin ders kitabını genel anlamda "kısmen yeterli" olarak gördükleri sonucuna ulaşılmıştır. Yapılan bir araştırmada ilköğretim matematik kitabı öğretmen görüşlerine göre incelenmiş ve bu araştırmada da öğretmenlerin ders kitabında bulunan etkinlikleri bu zihinsel beceriler bağlamında yeterli olarak görmedikleri sonucuna ulaşılmıştır (Taşdemir, 2011). Taşdemir (2011)'e göre; öğrenme ve öğretme sürecinde öğrencileri bu türden zihinsel becerileri kullanmaya sevk etmek, sürecin öğrenciler açısından aktif olarak geçmesine ve öğrencilerin yeni öğrenmelerini zihinlerinde yapılandırmasında yardımcı olmaktadır.

Araştırma neticesinde araştırmacı tarafından hazırlanan anket formun alt boyutlarına ilişkin sınıf öğretmenlerinin, Birinci Sınıf Türkçe Illk Okuma ve Yazma Kitabı'nın fiziksel tasarım, görsel tasarım ve alan bilgisi(bilimsellik) alt boyutlarına ilişkin daha olumlu görüşlere sahip olduğu, öğrenme ve öğretme süreci, kazanımlar, ölçme ve değerlendirme ve içerik alt boyutlarına ilişkin ise daha olumsuz görüşlere sahip olduğu ortaya çıkarılmıştır. Yani buna göre sınıf öğretmenleri ders kitabında bulunan ölçme, değerlendirme ve içeriksel öğeleri daha yetersiz olarak görmektedirler. Daha önce yapılmış bir araştırmada da öğretmenler ders kitabında bulunan alıştırma ve değerlendirmeye yönelik çalışmaların yeterli olmadığını, öğrencilerin bu çalışmalar neticesinde yeterince gelişemeyeceğini söyledikleri ortaya konmuştur (Akın, 2007; Güven, 2011).

Araştırma kapsamında, Birinci Sınıf Türkçe ilk Okuma ve Yazma Kitabı'na ilişkin sınıf öğretmenlerinin cinsiyet değişkenine göre anlamlı bir şekilde farklılaşıp farklılaşmadığı incelenmiştir. Bu kapsamda yapılan analizler sonucunda sınıf öğretmenlerinin cinsiyetlerinin, ders kitabına yönelik görüşlerinde anlamlı bir etkisi olmadığı görülmüştür. Anlamlı bir farklılık olmamasına karşın araştırma bulguları incelendiğinde erkek sınıf öğretmenlerinin kadın sınıf öğretmenlerine kıyasla ders kitabına yönelik daha olumlu görüşlere sahip olduğu görülmüştür. Nalçacı (2011) da 5.Sınıf Sosyal Bilgiler Ders Kitabı'nı öğretmen görüşleri bağlamında eleştirel açıdan incelediği çalışmasında öğretmenlerin cinsiyet değişkeni açısından ders kitabına yönelik görüşlerinde anlamlı bir farklılığın tespit edilemediğini ancak bilimsel içerik açısından erkek öğretmenlerin lehine anlamlı bir farklılığa ulaştığını ortaya koymuştur. İrdelenen bu araştırma yapılan araştırmanın ilgili sonuçlarını destekler niteliktedir. 
Araştırma doğrultusunda toplanan veriler farklı değişkenler ile de karşılaştırılmaya devam edilmiştir. Birinci Sınıf Türkçe lilk Okuma ve Yazma Kitabı'na ilişkin sınıf öğretmenlerinin yaşlarının, ders kitabı hakkındaki görüşlerinde bir farklılaşmaya yol açıp açmadığını görmek amacıyla farklı analizler kullanılarak sınıf öğretmenlerinin yaş değişkeni bağlamında ders kitabına ilişkin görüşlerinin anlamlı bir şekilde farklılaşmadığı ortaya çıkarılmıştır. Herhangi bir anlamlı farklılık görülmemesine karşın ders kitabına yönelik görüşlere ilişkin bulgular incelenmeye devam edilmiş ve 37-41 yaş arasındaki sınıf öğretmenlerinin ders kitabına yönelik daha olumlu görüşlere sahip olduğu görülmüştür.

Araştırmaya ilişkin bir diğer önemli sonuç ise sınıf öğretmenlerinin mesleki deneyimlerinin Birinci Sınıf Türkçe illk Okuma ve Yazma Kitabı'na ilişkin görüşlerini anlamlı bir şekilde farklılaştırıp farklılaştırmadığııın belirlenmesidir. Bu kapsamda yapılan analizler sonucunda elde edilen bulgular 810 yıllık mesleki deneyime sahip olan sınıf öğretmenleri ile 2-4 yıl mesleki deneyime sahip olan sınıf öğretmenlerinin ders kitabına yönelik görüşleri arasında anlamlı bir farklılık olduğunu göstermiştir. Bu bağlamda araştırma bulguları incelendiğinde 8-10 yıllık mesleki deneyime sahip olan sınıf öğretmenlerinin Birinci Sınıf Türkçe illk Okuma ve Yazma Kitabı hakkında daha olumlu görüşlere sahip olduğu görülmüştür. 5. Sınıf Sosyal Bilgiler Ders Kitabı'nın öğretmen görüşleri bağlamında eleştirel bir bakış açısıyla incelendiği bir araştırmada öğretmenlerin kıdemlerinin yani mesleki deneyimlerinin araştırma sonuçlarını anlamlı şekilde farklılaştırmadığı ortaya koyulmuştur, buna rağmen 16-20 yıl ve 26 üstü yıl mesleki deneyime sahip öğretmenler arasında ders kitabının programa uygunluğu bağlamında 16-20 yıl mesleki deneyime sahip öğretmenler lehine anlamlı bir farklılığa ulaşılmıştır (Nalçacı, 2011).

Araştırma neticesinde sınıf öğretmenlerinin çalışmakta oldukları kurumun bağı bulunduğu yerleşim birimi değişkenine ilişkin de önemli sonuçlar elde edilmiştir. Buna göre köy yerleşim birimine bağlı kurumlarda çalışmakta olan sınıf öğretmenlerinin görüşleri ile büyükşehir yerleşim birimine bağlı kurumlarda çalışmakta olan sınıf öğretmenlerinin görüşleri arasında ve yine köy yerleşim birimine bağlı kurumlarda çalışmakta olan sınıf öğretmenlerinin görüşleri ile şehir yerleşim birimine bağlı kurumlarda çalışmakta olan sınıf öğretmenlerinin görüşleri arasında anlamlı farklılıklara rastlanmıştır. Bu bağlamda köy yerleşim birimine bağlı kurumlarda çalışmakta olan sınıf öğretmenlerinin şehir ve büyükşehir yerleşim birimlerine bağı kurumlarda çalışan öğretmenlerden ders kitabı bağlamında daha olumlu görüşlere sahip olduğu görülmüştür. Yani köy yerleşim biriminde bağlı kurumlarda çalışmakta olan sınıf öğretmenleri, şehir ve büyükşehir yerleşim birimine bağı kurumlarda çalışmakta olan sınıf öğretmenlerine göre, Birinci Sınıf Türkçe İlk Okuma ve Yazma Ders Kitabı'nın daha yeterli ve daha etkili olduğunu düşünmektedirler.

Araştırma kapsamında nicel anlamda elde edilen son veriler ise sınıf öğretmenlerinin mezuniyet durumu değişkenine ilişkin elde edilen verilerdir. Bu bağlamda elde edilen bulgular incelendiğinde Birinci Sınıf Türkçe lilk Okuma ve Yazma Kitabı'na ilişkin sınıf öğretmenlerinin mezuniyet durumu değişkenine ilişsin sonuçlar ortaya çıkarılmıştır. Buna göre sınıf öğretmenlerinin Birinci Sınıf Türkçe illk Okuma ve Yazma Kitabı'na ilişkin görüşlerinde mezuniyet durumu değişkeni açısından incelendiğinde anlamlı bir farklılık görülmemiştir. Yine araştırmanın bu kısmına ilişkin bulgular incelenmeye devam edildiğinde yüksekokul mezunu olup, sınıf öğretmenliği görevini yapmakta olan öğretmenlerin ders kitabını daha yeterli olarak gördükleri söylenebilmektedir. Lisans ve yüksek lisans mezunu öğretmenlerin ise yüksekokul mezunu öğretmenlere göre ders kitabını daha az yeterli gördükleri saptanmıştır.

\section{Nitel Bölüme iliş̧kin Sonuçlar ve Tartışma}

Bu bölümde araştırmanın nitel bölümünden elde edilen bulgular sunulmuş ve ilgili literatür çerçevesinde tartışılmıştır.

Araştırma kapsamında bu bölümde sınıf öğretmenlerine ilk okuma ve yazma öğretimi sürecinde genel olarak hangi kaynaklardan faydalandıkları sorulmuş ve sınıf öğretmenlerinin buna yönelik verdikleri cevaplar irdelenmiştir. Bu doğrultuda sınıf öğretmenlerinin yarısına yakını ilk okuma ve yazma öğretimi sürecinde kaynak olarak sadece ders kitaplarını kullandıklarını belirtmişlerdir. Yine elde edilen sonuçlar incelenmeye devam edildiğinde sınıf öğretmenlerinin süreç boyunca kaynak olarak etkileşimli tahta ve uygulamalarını, bazı farklı kaynak kitapları da oldukça fazla kullandıklarını 
belirttikleri görülmüştür. Lalău (2014) da araştırmasında sınıf öğretmenlerinin ders kitaplarını kullanırken bunun yanında bazı kaynaklara ihtiyacı olduğunu belirttikleri sonucuna ulaşmıştır. Bu kapsamda araştırma sonucunu etkileyen gerekçeler incelendiğinde içeriği zenginleştirmek adına ders kitaplarının böyle kaynaklara ihtiyacı olduğu gibi gerekçeler öne sürüldüğü görülmüştür. Yine Lalău (2014) yaptığı araştırmasında sınıf öğretmenlerinin öğrenme ve öğretme süreci boyunca farklı görsel kaynaklardan da sıklıkla faydalandığı, bunun sebebinin ise öğrencilerin bireysel farklılıklarına yönelik olarak öğrenme ve öğretme sürecini zenginleştirmek olduğu sonucuna ulaşmıştır.

Nitel bölümden elde edilen başka bir sonuç da sınıf öğretmenlerinin ilk okuma ve yazma sürecinde Birinci Sınıf Türkçe İlk Okuma ve Yazma Ders Kitabı’ndan ne kadar faydalandıklarına ilişkindir. Bu bölümde sınıf öğretmenlerinin çoğunluğunun ders kitabını süreç içerisinde oldukça fazla kullandıklarını belirtir cevaplar verdiği görülmüştür. Tüm süreç boyunca ders kitabından yararlanan sınıf öğretmenlerinin sayısı da oldukça fazladır.

Birinci Sınıf Türkçe İlk Okuma ve Yazma Ders Kitabı'nın yeterliliği bağlamında elde edilen sonuçlara bakıldığında sınıf öğretmenlerinin yarısına yakınının ders kitabını ilk okuma ve yazma öğretimi süreci çerçevesinde kısmen yeterli olarak gördükleri ortaya çıkarılmıştır. Illköğretim Birinci Sınıf Türkçe Ders, Çalışma ve Öğretmen Kılavuz Kitapları'nın öğretmen görüşleri bağlamında incelendiği bir araştırmada öğretmenlerin sadece ön bilgileri yoklama ve kazanımlar ile ilgili maddelere kısmen yeterli geri kalan tüm maddelere de olumlu yönde yanıtlar verdikleri görülmüştür (Şahin, 2008). Şahin (2010) de yaptığı çalışmasında i̇kinci Sınıf Türkçe ders ve çalışma kitaplarını öğretmen görüşleri bağlamında incelemiş ve araştırmasının ilgili kısmında sınıf öğretmenlerinin ders ve çalışma kitabını kısmen yeterli olarak gördüklerini belirtmiştir. Yapılan bu araştırma, mevcut sonuçları destekler niteliktedir. Yapılan başka bir çalışmada ise Beşinci Sınıf Sosyal Bilgiler Ders kitabı öğretmen görüşleri bağlamında incelenmiş ve öğretmenlerin sosyal bilgiler ders kitabı hakkında içerik, fiziksel yapı, tasarım gibi özellikler çerçevesinde olumlu görüşlere sahip olduğu görülmüştür (Nalçacı, 2011). Bu bölümden elde edilen bulgular incelenmeye devam edildiğinde sınıf öğretmenlerinin geriye kalan yarısı ise ders kitabını yeterli ve yeterli değil olarak nitelendirmişlerdir. Taş (2007) da yaptığı araştırmada sosyal bilgiler ders kitabını öğretmen görüşleri bağlamında incelemiş, yaptığı araştırma sonucunda öğretmenlerin ders kitabını genel itibariyle yeterli olarak gördüklerini belirtmiştir. Yapılan araştırmada öğretmenlerin ders kitabına yönelik sadece içerik boyutunu "kısmen yeterli" olarak gördükleri, ancak ders kitaplarında içeriğin düzenlenmesinin ders kitabının geneline oldukça etki ettiği vurgulanmıştır (Taş, 2007).

Araştırma kapsamında sınıf öğretmenlerinin, Birinci Sınıf Türkçe illk Okuma ve Yazma Ders Kitabı'nın yetersiz olarak gördükleri bölümleri olup olmadığını saptamak amacıyla da veriler toplanmıştır. Verilerin incelenmesi neticesinde sınıf öğretmenleri genel anlamda ders kitabında heceye geçiş ve kelimeye geçiş gibi önemli noktalarda yer alan etkinliklerin yetersiz olduğunu betimlemişlerdir. Yine bu bağlamda sınıf öğretmenlerinin en çok yetersiz olarak gördükleri ikinci noktanın ise ders kitabında yer alan çalışma alanları ve metinler olduğu ortaya çıkarılmıştır. İlkokul íkinci Sınıf Türkçe Ders Kitabı'ndaki metinlerin çocuk edebiyatı metin nitelikleri bağlamında incelendiği bir yüksek lisans tez çalışmasında kitapta bulunan metinlerin bazılarının dil ve anlatım, üslup, öğrencilerin düzeyine uygunluk gibi kriterler açısından uygun olmadığı ortaya konmuştur (Merdane, 2019). Yine İlkokul ikinci Sınıf Türkçe Ders Kitabı metinlerinin resim-metin ilişkisi bağlamında incelendiği başka bir yüksek lisans tez çalışmasında da kitapta bulunan bazı metinlerin konumlandırma, başlığı destekleme, öğrenciler tarafından tahmin edilebilme gibi yönlerinden bir takım eksikliklerin olduğu tespit edilmiştir (Yıldız, 2015). Daha önce yapılan başka bir çalışmada da İkinci ve Üçüncü Sınıf Türkçe Ders ve Çalışma Kitapları öğretmen görüşlerine göre eleştirel bir bakış açısıyla incelenmiş ve öğretmenlerin çalışma kitaplarında bulunan etkinliklerin bazı yönlerden eksik olduğunu, öğrencilere göre daha uyumlu ve daha fazla etkinlik oluşturulması gerektiğini söyledikleri ortaya konmuştur, incelenen bu araştırmada bulunan bu sonuç, yapılan araştırmanın bu kısmını destekler niteliktedir (Şahin, 2010). Bazı sınıf öğretmenlerinin verdikleri cevaplar çoğunluğu ifade etmemiş olsa bile araştırma açısından değerli görülmüştür. Bu kapsamda bazı sınıf öğretmenleri ders kitabının somutlaştırma yönünün yetersiz olduğunu dile getirmişlerdir. 10. Sınıf Fizik Ders Kitabı'nın son sınıf öğretmen adaylarının görüşlerine göre değerlendirildiği başka bir araştırmada öğretmen adayları ders kitabının bütünsel anlamda yeterli 
olduğunu ancak ölçme ve değerlendirme, etkinlik vb. alanlarda ise eleştirilebilecek düzeyde olduğunu belirtmişlerdir (Kavcar, Özkan, Arıkan ve Şengören, 2014).

Sınıf öğretmenlerine ders kitabının sadece yetersiz olarak görülen kısımları sorulmamış, ders kitabı bağlamında tam olarak yeterli gördükleri alanları da ifade etmeleri istenmiştir. Bu doğrultuda elde edilen bulgulara bakıldığında sınıf öğretmenlerinin büyük bir çoğunluğunun Birinci Sınıf Türkçe İlk Okuma ve Yazma Ders Kitabı'nın sesi tanıma ve hissettirme yönlerini tam olarak yeterli gördükleri ortaya çıkarılmıştır. Yine bu bölümde elde edilen önemli bir sonuç ise sınıf öğretmenlerinin bazılarııın da ders kitabının görsellerinin ve tasarımsal özelliklerinin yeterli olduğunu betimlemeleridir. Şahin (2010) de ỉkinci ve Üçüncü Sınıf Türkçe ders kitaplarını öğretmen görüşlerine göre eleştirel bir bakış açısıyla incelediği çalışmasında, öğretmenlerin ders kitaplarının tasarımı bağlamında olumlu görüşlere sahip olduklarını ortaya koymuştur. Birinci Sınıf Türkçe Ders, Çalışma ve Öğretmen Kılavuz Kitapları'nın öğretmen görüşlerine göre incelendiği başka bir çalışmada ise öğretmenlerin ders kitaplarına yönelik tasarımsal anlamda bazı yetersizlikler gördükleri ve ders kitabının bu bölümünü kısmen yeterli olarak nitelendirdikleri görülmüştür (Şahin, 2008). Bunun sebebi olarak öğretmenler tasarımsal anlamda harita, fotoğraf, resim vb. unsurlara yeterince yer verilmediğini göstermişlerdir. Çaydere (2010) tarafından yapılan Birinci Sınıf Türkçe ilk Okuma ve Yazma Kitabı́nda bulunan görsellerin sanatsal tasarım ilkeleri bağlamında incelendiği bir yüksek lisans tez çalışmasında kitapta bulunan görsellerin sanatsal tasarım ilkeleri genelinde, genel anlamda uygun olarak görülmediği sonucuna ulaşılmıştır. Bu bağlamda yapılan araştırma sonucunu destekler nitelikte değildir. Yapılan araştırmada sınıf öğretmenlerinin görsel ve tasarımsal ögeler gibi özellikleri yeterli gördükleri ortaya çıkarılmıştır. Taş (2007) yaptığı araştırmasında sosyal bilgiler ders kitabını öğretmen görüşleri çerçevesinde incelemiş ve öğretmenlerin incelenen ders kitabı hakkında, ders kitabının dış kapak tasarımı, grafik tasarımı, dil, anlatım ve üslup ve dış tasarım gibi özelliklerini yeterli olarak gördüklerini belirtmiştir.

\section{Öneriler}

Bu bölümde yapılan araştırma bağlamında daha sonra başka araştırmacılar tarafından yapılacak olan araştırmalara ve araştırmanın uygulamasına yönelik önerilere yer verilmiştir.

\section{Uygulamaya Yönelik Öneriler}

- ilk okuma ve yazma ders kitabının öğrenme ve öğretme sürecinde kullanılmasında sınıf öğretmenleri sadece tek bir kaynağa bağlı kalmak yerine, öğrencilerin bireysel farklııklarına da hitap edebilecek şekilde daha farklı kaynaklar da kullanarak öğrenme ve öğretme sürecini zenginleştirebilirler.

- Hazırlanacak olan ilk okuma ve yazma ders kitaplarında öğretmenlerin sınıf içerisinde, okuma ve yazma öğretimi süreçleri de göz önünde bulundurularak daha fazla etkinliğe, hece ve kelimeye geçiş çalışmalarına yer verilebilir.

- Hazırlanacak olan ilk okuma ve yazma kitaplarında öğrencilerin bireysel seviyelerine uygun olacak şekilde daha fazla ölçme ve değerlendirme etkinliklerine yer verilebilir.

- Hazırlanacak olan ilk okuma ve yazma kitaplarında hece ve kelimeye geçiş süreçlerinden sonra gerek okuma gerekse yazma bağlamında kullanılmak üzere daha anlamlı ve daha fazla metne yer verilebilir.

- İlk okuma ve yazma ders kitabının öğrencilerin farklı duyularına da hitap edebileceği şekilde düzenlenmesi önerilebilir.

- Illk okuma ve yazma kitabında yapılacak olan düzenlemelerin sınıf ortamında ve öğrenmeöğretme sürecinde tam anlamıyla kullanılabilmesi için tüm sınıflarda asgari düzeyde teknolojik materyalin sağlanması önerilebilir.

\section{Yapılacak Araştırmalara Yönelik Öneriler}

- Araştırma kapsamında elde edilen sonuçlar genel olarak değerlendirildiğinde incelenen ders kitabı bağlamında önemli veriler elde edildiği ve ilgili ders kitabının farklı özellikleri açısından detaylı sonuçlara ulaşıldığı görülmektedir. Yapılan araştırma farklı alanlardaki farklı ders kitapları kapsamında da yapılabilir. 
- Araştırma sürecinde yapılacak her görüşme ve görüşmenin yapılacağı yer, zaman gibi önemli ayrıntılar araştırmacı tarafından önceden planlanmalı, buna göre programlar oluşturulmalı ve araştırmanın her anında elde edilen veriler ve bu durumlara ilişkin gelişmeler kayıt altına alınmalıdır.

- Dikkat edilmesi gereken başka bir nokta formların uygulanması süreci öncesinde katılımcılarla aktif bir şekilde görüşmek, katılımcılara formlar hakkında bilgi vermek ve katılımcıların içinde bulundukları duruma göre formu uygulayıp uygulamamaya karar vermek olarak göze çarpmaktadır. Bu önemli husus, araştırma sürecinde daha nitelikli veriler elde etmeyi ve araştırmanın geçerlik ve güvenirliğini doğrudan etkileyecektir.

- Yapılan araştırmanın uygulama aşamasında bazı sorunlarla karşılaşılmıştır. Bu kapsamda karşılaşılan sorunlardan ilki veri toplama aracının uygulanması aşamasında bazı katılımcıların araştırmaya gereken önemi vermemesinden kaynaklanmakta ve bu doğrultuda araştırma için toplanan verilerin niteliğini bozacak bazı formların elde edilmesiyle sonuçlanmaktadır. Böyle bir sorunla karşılaşıımaması adına yapılacak araştırmalarda katılımcıların araştırmaya yönelik güdülenmeleri artırılmaya çalışılmalıdır.

- Yapılan araştırmada araştırmacı tarafından hazırlanan veri toplama araçları kullanılmıştır. Bu kapsamda İlkokul Birinci Sınıf Türkçe İlk Okuma ve Yazma Kitabı'nın farklı özelliklerini belirlemeye yönelik hazırlanabilecek, farkı veri toplama araçları kullanılarak öğretmenlerin ilgili ders kitabına yönelik farklı görüşlerine ulaşılabilmesi sağlanabilir ve alanyazına farkı noktalardan kaynak oluşturulabilir.

- Yapılan araştırma, incelenen ders kitabının tamamına yönelik öğretmenlerin görüşlerini saptamak üzerine yapılmış ve bu doğrultuda ilerleme kaydedilmiştir. Araştırmacılar yapacakları çalışmalarda; metinler, görseller, programa uygunluk gibi ögeler açısından ders kitaplarını daha detaylı bir şekilde inceleyebilirler.

- Araştırmacılar yapılan araştırma kapsamında öğretmenlerin ders kitapları ile birlikte öğrenme ve öğretme sürecinde, ilk okuma ve yazma öğretimi sürecinde, hangi kaynakları, ne şekilde ve niçin kullandıklarını belirlemek amacıyla farklı çalışmalar yapabilirler.

- Sınıf içerisinde, öğrenme ve öğretme süreci çerçevesinde öğretmenlerin ders kitaplarını ne şekilde kullandığına dair araştırmalar yapılabilir.

- Ders kitaplarının etkililiğini belirlemeye yönelik olarak, deneysel desende yürütülebilecek araştırmalar yapılabilir.

\section{Kaynaklar}

Akın, B.i. (2007). "2005-2006 öğretim yılı ilköğretim okulları hayat bilgisi ders kitaplarının pedagojik açıdan değerlendirilmesi." Yayımlanmamış yüksek lisans tezi. Erciyes Üniversitesi Sosyal Bilimler Enstitüsü; Kayseri.

Alkan, V., Şimşek, S., ve Erbil, B. A. (2019). Karma yöntem deseni: Öyküleyici alanyazın incelemesi. Eğitimde Nitel Araştırmalar Dergisi, 7(2), 559-582.

Arslan, S.,ve Özpınar, í. (2008). Öğretmen nitelikleri: Illköğretim programlarının beklentileri ve eğitim fakültelerinin kazandırdıkları. Necatibey Eğitim Fakültesi Elektronik Fen ve Matematik Eğitimi Dergisi, 2(1), 38-63.

Bakar, E., Keleş, Ö., ve Koçakoğlu, M. (2009). Öğretmenlerin MEB 6. sınıf fen ve teknoloji dersi kitap setleriyle ilgili görüşlerinin değerlendirilmesi. KEFAD, 10(1), 41-50.

Can, A. (2017). SPSS ile bilimsel araştırma sürecinde nicel veri analizi. (5. Baskı). Ankara: Pegem Akademi.

Çaydere, O. (2010). ilköğretim 1. kademe 1. sınıfta ilkokuma ve yazma derslerinde kullanılan ders kitabında yer alan görsellerin hazırlanmasında sanatsal tasarım ilke ve elemanlarının kullanım durumu. Yayımlanmamış yüksek lisans tezi. Gazi Üniversitesi, Eğitim Bilimleri Enstitüsü: Ankara.

Demirel, Ö., Seferoğlu, S. S., ve Yağcı, E. (2004). Öğretim teknolojileri ve materyal Ankara: Pegem A Yayıncılık.

geliştirme. 
Geçit, Y., ve Yarar, S. (2010). 9. sınıf coğrafya ders kitabındaki sorular ile çeşitli coğrafya sınav sorularının Bloom Taksonomisine göre analizi. Marmara Coğrafya Dergisi, 22(1), 154-167.

Güven, S. (2010). İlköğretim hayat bilgisi dersi ders ve öğrenci çalışma kitaplarının

öğretmen görüşlerine göre değerlendirilmesi. Eğitim ve Bilim, 35(156), 84-95.

Kabapınar, Y. (2009). Yeni öğrenme anlayışının ışığında sosyal bilgiler ders

kitapları. Sosyal Bilgiler Öğretimi lç̧inde, 367-401.

Kavcar, N., Özkan, G., Arıkan, G., ve Şengören, S. K. (2014). Fizik öğretmen adaylarııın MEB'nca önerilen 10. sınıf fizik ders kitabına ilişkin görüşlerinin değerlendirilmesi. Ondokuz Mayıs Üniversitesi Eğitim Fakültesi Dergisi, 33(2), 549-570.

Küçükahmet, L. (2000). Öğretimde planlama ve değerlendirme (11. Baskı). Ankara: NobelYayın Dağıtım.

Lalau, E. (2014). Teachers', pupils', and parents' opinions on primary textbooks: Their selection, quality and use. Acta Didactica Napocensia, 7(3), 59-71.

Liman, S. (2007). Illköğretim 1. kademe ders kitabı illüstrasyonlarının tasarım ilkelerine ve öğrencilerin algı düzeyine uygunluğu. Yayımlanmamış yüksek lisans tezi. Gazi Üniversitesi, Eğitim Bilimleri Enstitüsü: Ankara.

Nalçacı, A. (2011). Illköğretim 5. sınıf sosyal bilgiler ders kitabının öğretmen görüşlerine göre değerlendirilmesi (Erzurum örneği). Atatürk Üniversitesi Sosyal Bilimler Enstitüsü Dergisi, 15(2), 321-335.

Öcal, A., ve Yiğittir, S. (2007). İlköğretim sosyal bilgiler ders kitaplarının öğretmen görüşlerine göre değerlendirilmesi (Kırıkkale örneği). Ahi Evran Üniversitesi Kırşehir Eğitim Fakültesi Dergisi, 8(1), 51-61.

Şahin, A. (2008). ilköğretim birinci sınıf Türkçe ders kitabı, öğrenci çalışma kitabı ve öğretmen kılavuz kitabının öğretmen görüşlerine dayalı olarak değerlendirilmesi. Ahi Evran Üniversitesi Kırşehir Eğitim Fakültesi Dergisi, 9(3), 133-146.

Şahin, A. (2010). Illköğretim ikinci ve üçüncü sınıf Türkçe ders kitabı, öğrenci çalışma kitabı ve öğretmen kılavuz kitabının öğretmen görüşlerine dayalı olarak değerlendirilmesi. Milli Eğitim Dergisi, 40(185), 48-65.

Taş, A. M. (2007). Yeni sosyal bilgiler ders kitaplarına ilişkin öğretmen görüşlerinin belirlenmesi. Selçuk Üniversitesi Sosyal Bilimler Enstitüsü Dergisi, 1(17), 519532.

Taşdemir, C. (2011). illköğretim 1. kademede okutulan matematik ders kitaplarının öğretmen görüşlerine göre değerlendirilmesi. Dicle Üniversitesi Ziya Gökalp Eğitim Fakültesi Dergisi, 16(2011), 16-27.

Yıldırım, A. (2006). Yeni ilköğretim programına göre hazırlanmış hayat bilgisi ders kitaplarına ilişkin öğretmen görüşlerinin incelenmesi (Elazığ örneği). Yayımlanmamış yüksek lisans tezi. Fırat Üniversitesi Sosyal Bilimler Enstitüsü; Elazığ.

Yıldırım, A., ve Simsek, H. (2008). Sosyal bilimlerde nitel araştırma yöntemleri. Ankara: Seçkin. Yıldırım, K. (2010). Nitel araştırmalarda niteliği artırma. ilköğretim Online, 9(1), 79-92.

\section{Introduction}

\section{Extended Abstract}

With the developing technology, written materials have started to be found not only in paper materials but also in electronic media. Books are now available as e-books on the internet; It has enabled the concept of reading from the screen to emerge through technological devices such as tablets, computers and phones. Considering the technological infrastructure conditions of the world and our country, the widespread use of screen reading is possible in limited areas. The existence of different infrastructural problems in front of the technological diffusion of knowledge may once again lead to the need to use textbooks. The quality of the learning and teaching process can be increased by preparing the textbooks by a resource in line with the curriculum and lesson plans and delivering them to the target audience (Demirel, Seferoğlu, \& Yağcl, 2004; Geçit \& Yarar, 2010).It is not expected for a long time to lose its importance, as textbooks are still used as such an important teaching 
material. In this study, it was aimed to examine First Grade Elementary School Reading and Writing Textbook in the context of teachers' opinions.

\section{Method}

The research conducted is a mixed method research in that it includes quantitative and qualitative methods together.

Within the scope of the research, a questionnaire form was prepared by the researcher in order to determine the teachers' perceptions about the textbook. The data collected through this form constitute the quantitative dimension of the research. 191 classroom teachers working in elementary schools in Şanlıurfa province participated in the quantitative dimension of the study in the 2018-2019 academic year.

In order to make sense of the data obtained from the quantitative dimension of the research and to make it more explanatory, a semi-structured interview form was prepared by the researchers by referring to expert opinions and it was applied by interviewing 28 teachers from the current sample on a voluntary basis.

\section{Result and Discussion}

As a result of the research, it was concluded that the opinions of the classroom teachers about the First Grade Textbook were "partially sufficient". When the findings obtained from the research are continued to be examined, it can be concluded that teachers with 2-4 years of professional experience consider the textbook more sufficient than teachers with 8-10 years of professional experience.

Another result obtained from the study is that the elementary school classroom teachers working in the village settlement consider the textbook more adequate than the elementary school classroom teachers working in the city and metropolitan settlements.

In addition to all of these, the elementary school classroom teachers mostly saw the syllable and transition parts of the textbook incomplete, they stated that they considered the parts of the textbook related to phonics instruction are sufficient. 